\title{
Targeting the Janus Kinase Family in Autoimmune Skin Diseases
}

\author{
Michael D. Howell ${ }^{\dagger}$, Fiona I. Kuo ${ }^{\dagger}$ and Paul A. Smith ${ }^{\star+}$ \\ Incyte Corporation, Wilmington, DE, United States
}

Autoimmune skin diseases are characterized by significant local and systemic inflammation that is largely mediated by the Janus kinase (JAK)-signal transducer and activator of transcription (STAT) pathway. Advanced understanding of this pathway has led to the development of targeted inhibitors of Janus kinases (JAKinibs). As a class, JAK inhibitors effectively treat a multitude of hematologic and inflammatory diseases. Growing evidence suggests that JAK inhibitors are efficacious in atopic dermatitis, alopecia areata, psoriasis, and vitiligo. Additional evidence suggests that JAK inhibition might be broadly useful in dermatology, with early reports of efficacy in several other conditions. JAK inhibitors can be administered orally or used topically and represent a

OPEN ACCESS

Edited by:

Ralf J. Ludwig,

Universität zu Lübeck, Germany

Reviewed by:

Massimo Gadina,

National Institute of Arthritis and Musculoskeletal and Skin Diseases

(NIAMS), United States

Kunihiro Yamaoka,

Keio University School of Medicine,

Japan

${ }^{*}$ Correspondence:

Paul A. Smith

psmith@incyte.com

tThese authors have contributed equally to this work

Specialty section:

This article was submitted to Autoimmune and Autoinflammatory

Disorders,

a section of the journal

Frontiers in Immunology

Received: 07 August 2019 Accepted: 17 September 2019

Published: 09 October 2019

Citation:

Howell MD, Kuo Fl and Smith PA (2019) Targeting the Janus Kinase Family in Autoimmune Skin Diseases. Front. Immunol. 10:2342. do: 10.3389/fimmu.2019.02342 promising new class of medications. Here we review the evolving data on the role of the JAK-STAT pathway in inflammatory dermatoses and the potential therapeutic benefit of JAK-STAT antagonism.

Keywords: Janus kinase, cytokines, skin barrier, dermatology, autoimmunity

\section{JAK-STAT SIGNALING PATHWAY}

The mammalian Janus kinase (JAK) family contains three JAKs (JAK1-3) and tyrosine kinase 2 (TYK2), which selectively bind different receptor chains (1). Upon binding of ligand to its cognate cytokine receptor, associated JAKs become activated and undergo autophosphorylation and transphosphorylate the intracellular tail of their receptors. This creates docking sites for the $\mathrm{SH} 2$ domain of the cytoplasmic transcription factors termed signal transducers and activators of transcription (STATs). The human STAT family contains seven STATs: STAT1, STAT2, STAT3, STAT4, STAT5A, STAT5B, and STAT6. Following phosphorylation, STATs are translocated to the nucleus, dimerize, and bind to specific DNA sequences to regulate gene transcription (2). The JAK-STAT pathway is pivotal for the downstream signaling of inflammatory cytokines, including interleukins (ILs), interferons (IFNs), and multiple growth factors $(3,4)$. Overall, the selective use of JAKs by different receptors coupled to downstream STAT signal transduction results in an elegant mechanism to achieve exquisite in vivo specificity for more than 60 cytokines and growth factors (Figure 1).

Identification of selective pharmacologic JAK inhibitors (JAKinibs) has been an ongoing research and development goal. The first JAKinib to gain FDA approval in 2011 was ruxolitinib for intermediate or high-risk myelofibrosis, thereby showing that JAK inhibition was not only possible, but safe and effective for its intended uses. More recently, selective JAK inhibitors have been explored for specific inflammatory disease indications (Table 1).

\section{THE JAK-STAT PATHWAY AND T HELPER SUBSETS}

The differential fate of naive $\mathrm{T}$ cells into committed $\mathrm{T}$ helper (Th) subsets is orchestrated under the instruction of professional antigen-presenting cells within a JAK-STAT-dependent cytokine 
milieu (Figure 2). In vivo Th1 differentiation depends on JAKmediated signaling through the IFN $\gamma$ receptor (IFNGR), the IL12 receptor (IL-12R), and downstream STAT1/4 phosphorylation culminating with T-bet gene transcription (5). Ultimately, IFN $\gamma$ signaling initiates the Th1 differentiation program and IL-12 perpetuates it. In contrast, Th2 cells arise after occupancy of the IL-4R $\alpha$ by its ligands IL-4 and IL-13, triggering JAK1/3 and subsequent activation of STAT6 (6), and leading to transcriptional regulation of the GATA3 target gene (5). More recently, the critical role of IL-17-producing Th cells (termed Th17 cells) in host defense against extracellular bacteria, maintenance of epithelium barrier integrity, and autoimmune pathogenesis has become increasingly clear. Within the immunologic microenvironment, IL-6 produced by activated dendritic cells (DCs) is a key factor in promoting Th17 differentiation via STAT3 and retinoic acid receptor-related orphan receptor $\gamma(\mathrm{ROR} \gamma \mathrm{t}$ ) induction (7) with IL-23 critical for memory Th17 in vivo function $(3,8)$.

\section{ATOPIC DERMATITIS}

Atopic dermatitis (AD) is a chronic, inflammatory skin disease that typically begins in early childhood and occurs more frequently in families with a history of other atopic diseases (bronchial asthma and/or allergic rhinoconjunctivitis). Overall, the prevalence of $\mathrm{AD}$ is up to $20 \%$ in children and $10 \%$ in adults, with rates varying geographically $(9,10)$. AD clinically manifests as recurrent eczematous lesions that negatively affect quality of life through sleep disturbances due to chronic itch (pruritus) $(11,12)$, increased likelihood of developing depression (13), and significant economic burden (14).

The cellular infiltrate of $\mathrm{AD}$ lesions mainly consist of $\mathrm{CD} 4^{+}$ $\mathrm{T}$ cells, which are considered key drivers of inflammation (15). Lesional skin is characterized by an overexpression of inflammatory Th2-cytokines (IL-4, IL-13, IL-31), and Th22cytokines (IL-22) (16). Crucially, the cytokines IL-4, IL-13, IL-31, and IL-22 require JAK-STAT downstream signaling (3) for their biological function (Figure 3). Spontaneous and induced rodent dermatitis models have been extensively used

Abbreviations: AA, Alopecia areata; ACT, Nuclear factor NF-kappa-B activator 1; AD, Atopic dermatitis; BID, Twice daily; CD, Cluster of differentiation; CXCL, Chemokine (C-X-C motif) ligand; CXCR, Chemokine (C-X-C motif) receptor; DC, Dendritic cell; DNCB, 2,4-dinitrochlorobenzene; EASI, Eczema Area Severity Index; EPO, Erythropoietin; FDA, US Food and Drug Administration; FLG, Filaggrin; GATA-3, GATA transcription factor 3; GH, Growth hormone; GM-CSF, Granulocyte-macrophage colony-stimulating factor; IFN, Interferon; Ig, Immunoglobulin; IL, Interleukin; ILC2, Type 2 innate lymphoid cells; IGA, Investigator global assessment; INV, Involucrin; JAK, Janus kinase; JAKinibs, Janus kinase inhibitors; LOR, Loricrin; MHC, Major histocompatibility complex; NK, Natural killer cell; NKD2D, Natural Killer Group 2D; NKD2DL3, Natural Killer Group 2D ligand 3; PASI, Psoriasis Area and Severity Index; pDC, Plasmacytoid dendritic cell; PGA, Physician Global Assessment; QD, Once daily; OSM, Oncostatin M; OSMR $\beta$, Oncostatin M receptor $\beta$; PI3K, Phosphoinositide 3-kinases; RAET1L, Retinoic acid early transcript 1L; ROR $\gamma$ t, Retinoic acid receptor-related orphan receptor $\gamma$; SALT, Severity of Alopecia Tool; STAT, Signal transducer and activator of transcription; T-bet, T-box transcription factor TBX21; TGF, Transforming growth factor; Th, T helper; TNF $\alpha$, Tumor necrosis factor alpha; TPO, Thrombopoietin; TSLP, Thymic stromal lymphopoietin; TYK2, Tyrosine kinase 2; VASI, Vitiligo Area Scoring Index. to explore the effectiveness of small-molecule JAK inhibitors on reducing inflammation. Delgocitinib (pan-JAK) inhibited skin inflammation in hapten-induced chronic dermatitis in mice, as evidenced by reduced levels of inflammatory cytokines in the skin and IgE in serum (17). In addition, momelotinib (JAK1/JAK2) downregulated IL-4 expression, reduced the skin severity scores and reduced total serum IgE levels in the 2,4dinitrochlorobenzene (DNCB)-induced AD mice (18). Similarly, tofacitinib (JAK1/3) and oclacitinib (JAK1) inhibited the production of proinflammatory Th2 cytokines, including IL4, in the toluene-2,4-diisocyanate (TDI) dermatitis model (19). Moreover, tofacitinib demonstrated anti-inflammatory activity in the oxazolone-induced chronic allergic contact dermatitis model (20).

Interleukin-22 is elevated in $\mathrm{AD}$ lesions and is associated with epidermal thickening, skin barrier disruption, and increased expression of thymic stromal lymphopoietin (TSLP) and IL-33 cytokines (21). In addition, IL-22 potently induces the expression of gastrin-releasing peptide, a neuropeptide pruritogen, in dermal cells, dermal afferent fibers, and skin innervating ganglion neurons that positively correlate with the scratching behavior (22). The relevance of IL-22 in AD pathogenesis was emphasized by the observation of sustained clinical improvements in patients with moderate to severe AD receiving anti-IL-22 therapy (23). IL-22 binds its cognate receptor comprising a heterodimeric complex of IL-22RA1 and IL-10R2 subunits, leading to activation of JAK1 and TYK2 and phosphorylation of STAT3 (24).

Thymic stromal lymphopoietin and IL-31 cytokines also significantly contribute to triggering of inflammatory itch, under the control of IL-4, IL-13, and IL-33 (25). Crucially, pruritogenic cytokines IL-31 and TSLP use JAK1 and JAK2 downstream signaling $(26,27)$. Additionally, preclinical evidence has confirmed that pharmacologic inhibition of the JAK-STAT pathway is sufficient for the amelioration of pruritus-associated dermatitis. Examples include oclacitinib, which is licensed for pruritus associated with allergic dermatitis in dogs (28). Similarly, topical application of ruxolitinib (JAK1/JAK2) ameliorated TSLP-induced inflammation in mice (29). In the TDI-induced mouse model of dermatitis, oclacitinib and tofacitinib inhibited itch symptoms and significantly reduced IL-31, tumor necrosis factor- $\alpha$ (TNF $\alpha$ ), and TSLP cytokine secretions (19). Moreover, TSLP can activate tissue resident dendritic cells that promote the transformation of Th-naïve lymphocytes to the Th2 phenotype thereby facilitating tissue inflammation (30). Finally, neuronal IL-4R $\alpha$ acting via JAK1 signaling can also significantly contribute to chronic itch (31).

Skin barrier disruption and the resulting continuous exposure to allergens are presumed to be responsible for the development of atopic dermatitis (AD). JAK1-mediated Th2 cytokines IL-4 and IL-13 acting in a STAT-dependent manner (32) negatively affect skin barrier integrity by inhibiting the expression of filaggrin, loricrin, and involucrin, resulting in destabilization of tight junctions $(33,34)$. JAK inhibition restored filaggrin and loricrin expression following in vitro pretreatment with IL-4/IL13 cytokines of human keratinocyte. Moreover, mice harboring a point mutation leading to JAK1-specific hyperactivation develop spontaneous skin barrier disruption and a dermatitis phenotype 


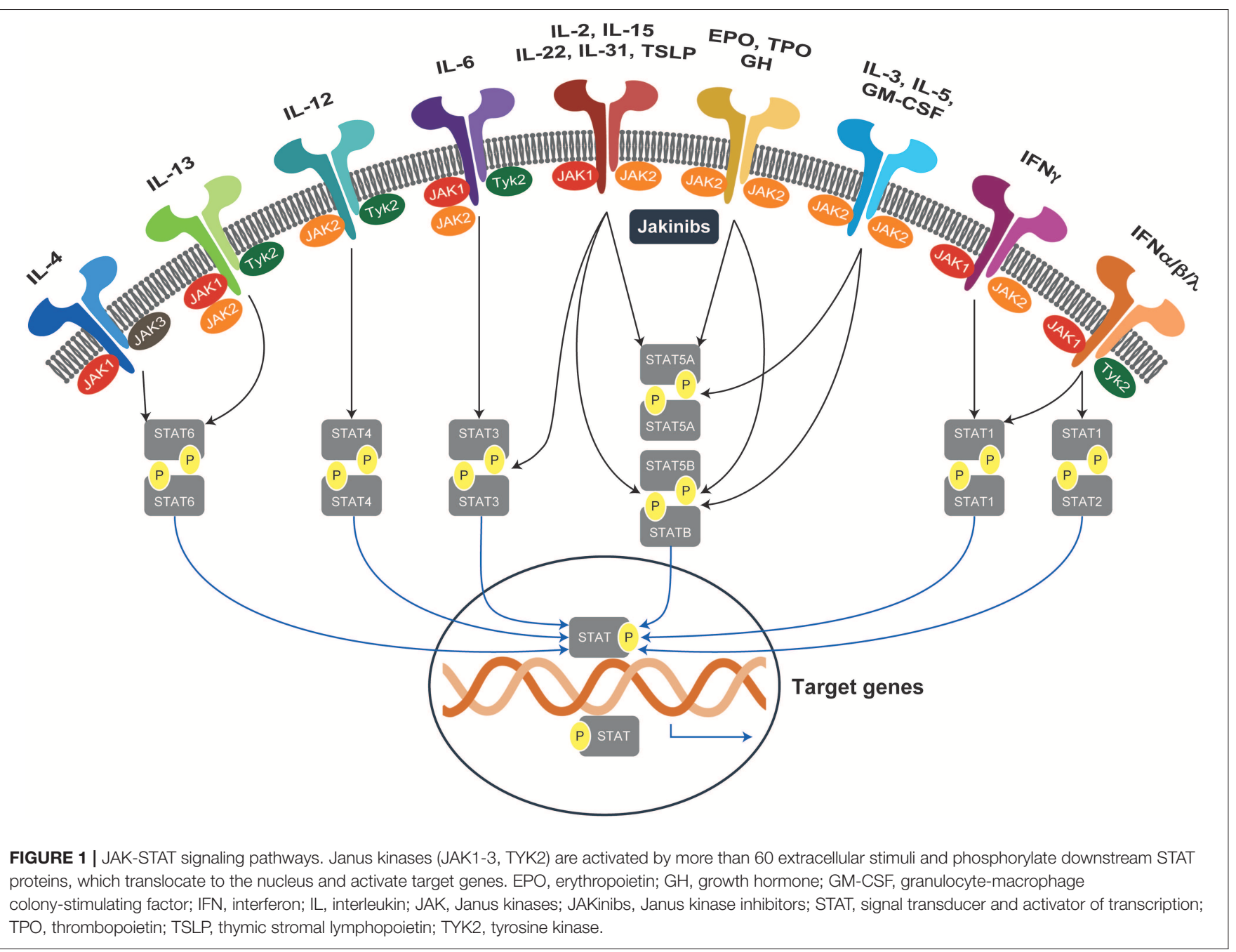

(35). Topical application of delgocitinib ameliorated spontaneous $\mathrm{AD}$-like skin inflammation and barrier disruption in an NC/Nga "dry skin" mouse model and restored filaggrin levels in an experimental human skin graft model leading to improved barrier function (36). Moreover, downstream signaling of IL4 and IL-13 also suppresses the induction of innate immune response genes, such as $\beta$-defensins (33), thereby facilitating skin microbiome dysbiosis, including aberrant Staphylococcus aureus colonization (37).

The role and activation of Th1 and Th17 cell-mediated responses require further elucidation, but these pathways appear to be overexpressed in chronic disease stages, children, and people of Asian ethnicity $(38,39)$.

Targeting the JAK family of kinases in $\mathrm{AD}$ has proven, in recent years, to be therapeutically beneficial. Oral tofacitinib administration was evaluated in 6 patients with moderate to severe $\mathrm{AD}$ and showed a promising reduction in skin severity (40). The next generation of orally administered JAKinibs includes baricitinib (JAK1/2) along with two JAK1 selective molecules, upadacitinib (JAK1) and abrocitinib (JAK1). In clinical trials in moderate to severe $\mathrm{AD}$ patients, oral administration of these JAKinibs significantly reduced the eczema area severity index (EASI) scores by more than $50 \%$. More specifically, in one clinical trial (ClinicalTrials.gov identifier, NCT02925117), oral administration of upadacitinib (JAK1) resulted in 90\% improvement in the eczema area severity index (EASI) score for $\sim 50 \%$ of enrolled participants after 16 weeks of treatment (41). Results from two baricitinib phase 3 studies showed that more patients achieved an investigator global assessment (IGA) 0/1 with barcitinib 4 mg once daily (QD) and $2 \mathrm{mg}$ QD than with placebo (42). Significant improvements in EASI and patient-reported outcomes were observed as early as Week 1 (Table 2) (53). In a recent phase 1 b study (NCT03139981), ASN002, a pan JAK inhibitor that also inhibits spleen tyrosine kinase (SYK), showed a 50\% improvement in EASI in $100 \%$ of participants within 4 weeks (56).

Topical administration of tofacitinib to patients with mild to moderate AD in a clinical trial (NCT02001181) demonstrated significant improvement in EASI scores at Week 4 (43) and improvement in pruritus as early as Day 2. In a phase 2 study (NCT03011892) involving patients with mild to moderate $\mathrm{AD}$ receiving ruxolitinib cream, mean percentage change 
TABLE 1 | Selectivity profiles of clinically active JAKinibs.

\begin{tabular}{|c|c|c|c|c|}
\hline Inhibitor & JAK1 & JAK2 & JAK3 & TYK2 \\
\hline Tofacitinib* & $x$ & $x$ & $x$ & \\
\hline $\begin{array}{l}\text { Ruxolitinib, }{ }^{\dagger} \text { Baricitinib, }{ }^{\ddagger} \\
\text { Momelotinib, CTP-543 }\end{array}$ & $x$ & $x$ & & \\
\hline $\begin{array}{l}\text { Oclacitinib, }{ }^{\S} \text { Itacitinib, } \\
\text { Upadacitinib, Filgotinib, } \\
\text { PF04965842, LP0184 }\end{array}$ & $x$ & & & \\
\hline ATI-502 & $x$ & & $x$ & \\
\hline PF-06700841 & $x$ & & & $x$ \\
\hline PF-06651600 & & & $x$ & \\
\hline PF-06826647 BMS-986165 & & & & $x$ \\
\hline Delgocitinib (JTE-052) & $x$ & $x$ & $x$ & $x$ \\
\hline
\end{tabular}

JAK, Janus kinase; JAKinibs, inhibitors of Janus kinase; FDA, US Food and Drug Administration; TYK, tyrosine kinase.

${ }^{*} F D A$ approved: rheumatoid arthritis, psoriatic arthritis and ulcerative colitis.

${ }^{\dagger}$ FDA approved: adults with polycythemia who have had an inadequate response to or are intolerant of hydroxyurea, adults with intermediate or high-risk myelofibrosis, acute graft-vs. -host disease in adult and pediatric patients 12 years and younger.

¥FDA approved: rheumatoid arthritis.

${ }^{\S}$ FDA approved: atopic dermatitis and pruritus from allergic dermatitis in dogs.

from baseline at Week 4 in EASI score demonstrated a significant improvement and was non-inferior to triamcinolone. Interestingly, significant reductions in itch were noted as early as 1 day after initiation of therapy $(64,65)$. More recently, pilot studies of topical ATI-502 (JAK1/3) solution (NCT03585296) and PF-06700841 (JAK1/TYK2) cream (NCT03903822) in AD are ongoing. Given the early successes of JAKinibs in $\mathrm{AD}$, ongoing investigation and evaluation is expected to further elucidate the differential effects of JAK selectivity.

\section{ALOPECIA AREATA}

Alopecia areata (AA) is an autoimmune disease resulting in partial or complete nonscarring hair loss, with a prevalence of $\sim 1.7$ to $2.1 \%$ (68). Susceptibility to AA is indiscriminate between the sexes and ethnicities, with initial disease onset often occurring before the third decade of life. Early symptoms are typically characterized by small, well-defined patches of hair loss that may spontaneously resolve with time; however subsequent relapses occur in around a third of cases. Spontaneous remission is rare in patients with alopecia totalis or alopecia universalis. To date, no FDA- or European Medicines Agency-approved treatments exist.

Multiple lines of evidence have demonstrated that AA pathogenesis is autoimmune in nature, with loss of immune privilege and associated $\mathrm{T}$ cells infiltration selectively attacking growth at the hair follicle (i.e., anagen phase) (69-72). Healthy hair follicles achieve immune privilege at the anagen phase by downregulation of expression of major histocompatibility complex (MHC) class I and class II molecules $(70,73)$ and by expression of $\mathrm{NK}$ and $\mathrm{CD}^{+}$cell inhibitors, such as macrophage migration inhibitory factor (MIF) and transforming growth factors (TGF) $\beta 1$ and $\beta 2$, which generate an immunosuppressive microenvironment (74-76). Importantly, hair follicle epithelial stem cells are usually spared during the autoimmune attack, which provides a potential mechanism of hair growth recovery with effective anti-inflammatory treatment (70).

Many different mammalian species, including rodents, are susceptible to AA and this has facilitated preclinical models for the elucidation of cellular and molecular immune pathways $(77,78)$. The inbred $\mathrm{C} 3 \mathrm{H} / \mathrm{HeJ}$ strain spontaneously develops alopecia in up to $20 \%$ of mice via an IFN $\gamma$ - and inflammasomesensitive mechanism (79); however recipient $\mathrm{C} 3 \mathrm{H} / \mathrm{HeJ}$ animals that receive skin grafts from donor alopecic $\mathrm{C} 3 \mathrm{H} / \mathrm{HeJ}$ mice develop an accelerated phenotype with nearly $100 \%$ disease penetrance (80). Transfer or deletion of effector $\mathrm{CD}^{+} \mathrm{T}$ cells is sufficient to induce or block disease in preclinical models (70, $71,81)$, which in consistent with the observation that cytotoxic $\mathrm{CD}^{+} \mathrm{NKG}^{+} \mathrm{D}^{+} \mathrm{T}$ cells expressing granzyme B (82) infiltrate around the hair follicles and are major contributors of hair loss $(81,83)$.

Global transcriptional analyses of mouse and human affected skin identified expression signatures indicative of cytotoxic T-cell infiltration, such as increased production of IFN $\gamma$ and $\gamma$-chain $(\gamma c)$ cytokines, including IL-15 $(81,84)$. Furthermore, inhibiting IFN $\gamma$ either by genetic deletion or neutralizing antibody significantly ameliorates AA development and severity (85), supporting the hypothesis that IFN $\gamma$ drives AA pathogenesis by inducing ectopic expression of $\mathrm{MHC}$ molecules and ligands that stimulate NK-cell receptors (NKG2D) in the anagen hair bulb leading to the collapse of the hair follicle immune privilege (70, 86-88). An important cellular source of IFN is plasmacytoid dendritic cells (pDCs), which are normally absent from healthy skin, but migrate into tissues in response to inflammatory stimuli or infection. Infiltrating pDCs have been identified around hair follicles of patients with AA (89) and, upon activation, produce large quantities of type I IFNs (90).

The IFN $\gamma$-induced chemokine receptor CXCR3 and its ligands CXCL9 and CXCL10 are upregulated around hair follicles during early AA pathogenesis (Figure 4), thereby facilitating lymphocyte recruitment $(82,91)$. CXCR3 is primarily expressed on Th1 $\mathrm{CD}^{+}{ }^{+} \mathrm{T}$ cells, $\mathrm{CD} 8^{+} \mathrm{T}$ cells, NK, and PDCs during skin inflammation (92), whereas CXCR3 ligands are secreted by many tissue resident cells, including dendritic cells.

Like IFN $\gamma$, IL-15 enhances innate and self-reactive memory T-cell immunity, including autoimmune disease pathogenesis $(84,93)$, and signals via the JAK1/3 pathway with downstream STAT-5 activation (94). Similarly blocking IL-2 or IL-15 receptor beta (IL-15R $\beta$ ) ameliorated disease development by inhibiting $\mathrm{CD}^{+}{ }^{+} \mathrm{NKG} 2 \mathrm{D}^{+}$T-cell accumulation in the skin (81).

The combination of published genome-wide association studies in patients with AA that highlighted JAK signaling (87, 95) and the knowledge that IFN $\gamma$ primarily signals through JAK1/2 and IL-15 mostly through JAK1/3, provided a compelling rationale for the exploration of small-molecule JAK inhibitors in AA disease $(81,96)$. Preclinical evaluation of orally administered ruxolitinib and tofacitinib in the skin graft $\mathrm{C} 3 \mathrm{H} / \mathrm{HeJ}$ mouse model demonstrated disease prevention (81). Marked decreases of CD4, CD8, and MHC class I and II as well as a reduced numbers of $\mathrm{CD}^{+} / \mathrm{NKG} \mathrm{D}^{+}$cells were observed in the skin (81). Subsequently, prophylactic and therapeutic baricitinib treatment ameliorated disease and normalized the Alopecia 

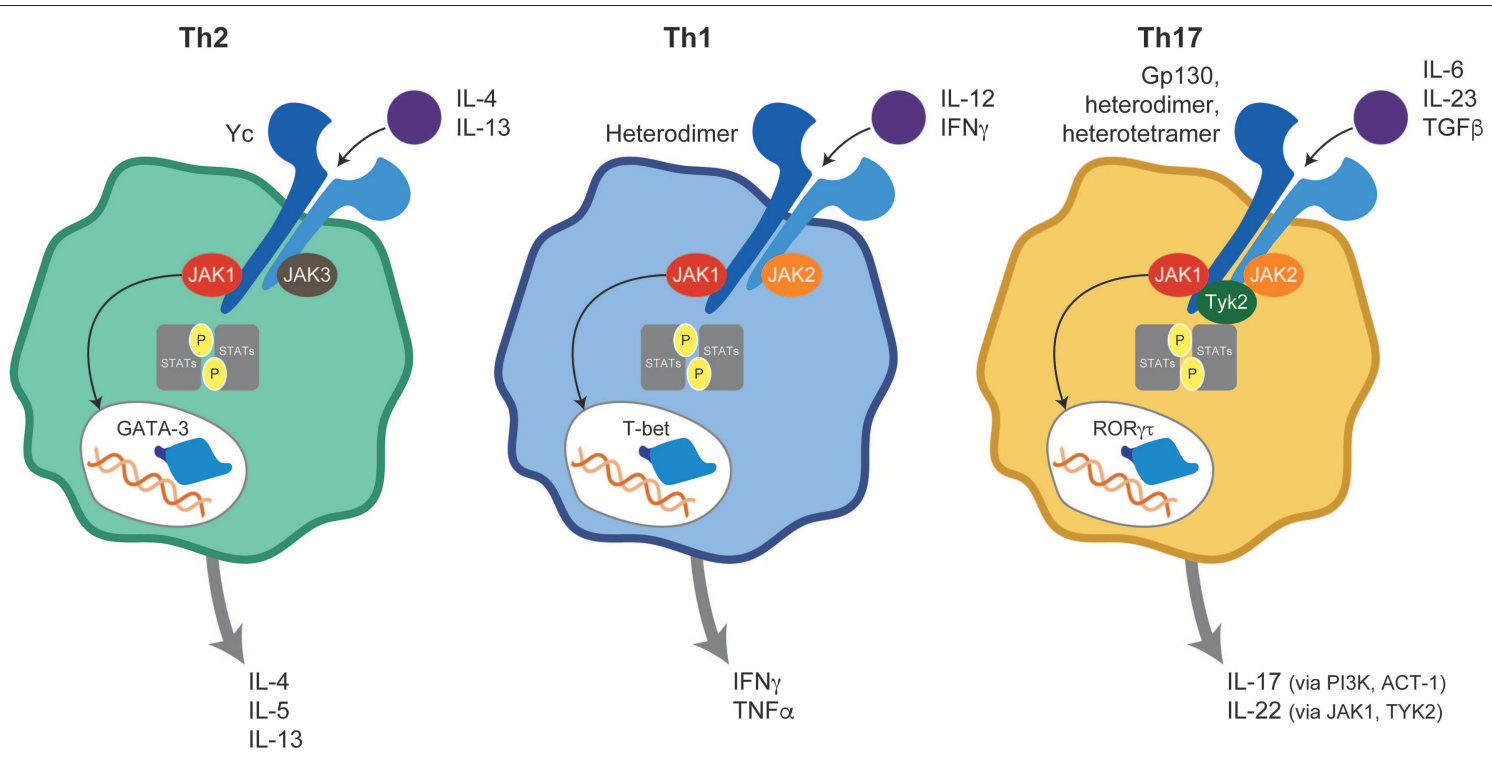

FIGURE 2 | JAK-mediated cytokine signaling in T helper subsets. Ligand binding to its cognate receptor triggers JAK-STAT activation and plays a central role in naive T-cell differentiation into Th1, Th2, and Th17 subsets. ACT, Nuclear factor NF-kappa-B activator 1; GATA, GATA transcription factor 3; IFN, interferon; IL, interleukin; JAK, Janus kinase; PI3K, Phosphoinositide 3-kinases; ROR $\gamma$ t, retinoic acid receptor-related orphan receptor $\gamma$; STAT, signal transducer and activator of transcription; T-bet, T-box transcription factor TBX21; Th, T helper; TGF, transforming growth factor; TNF, tumor necrosis factor; TYK, tyrosine kinase.

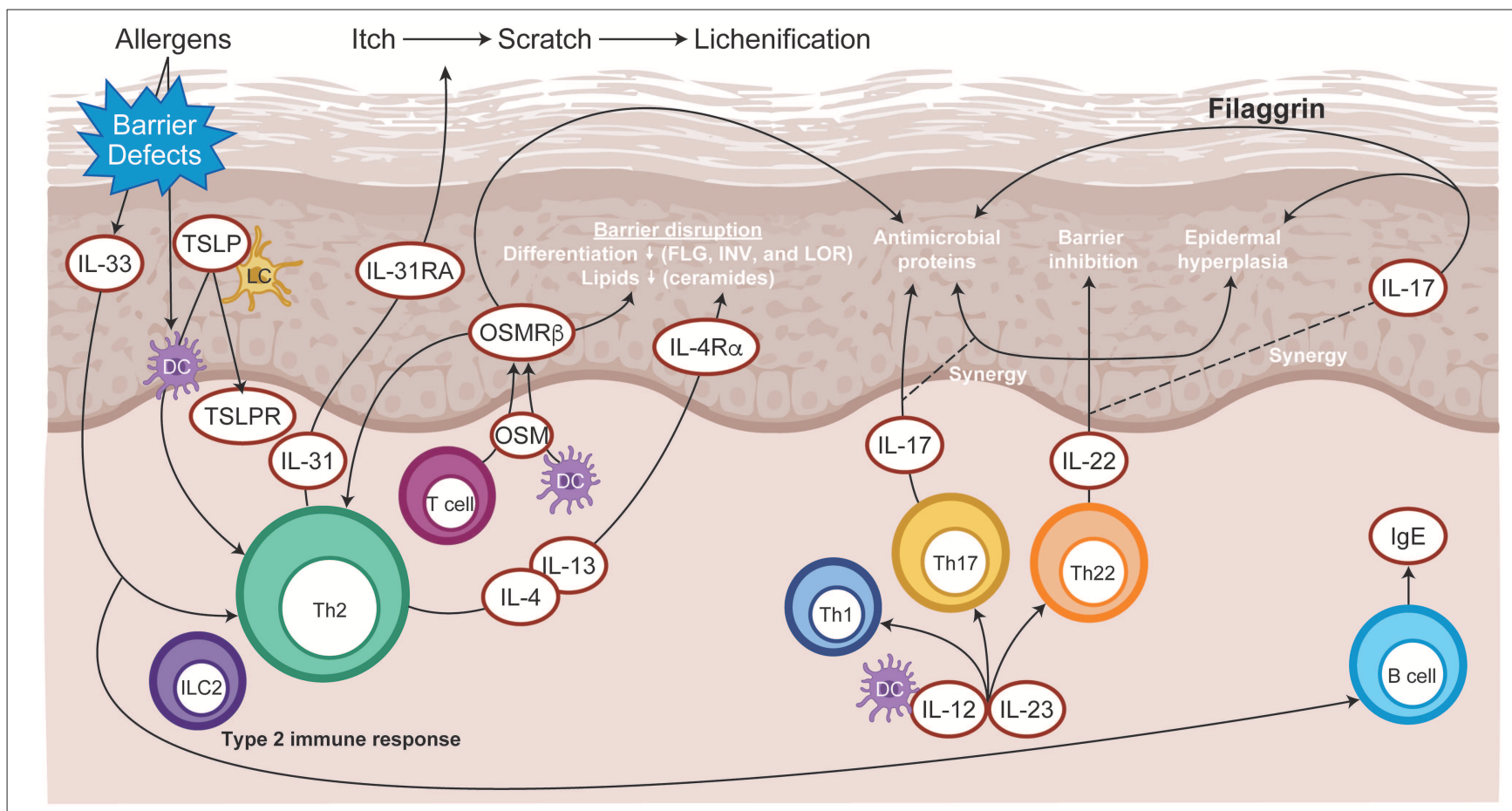

FIGURE 3 | Immunopathogenesis of atopic dermatitis. Allergen entry through the disrupted epidermal barrier stimulates keratinocytes to express cytokines, such as IL-33 and TSLP, which trigger ILC2 and Th2 cell mediated inflammation. Skin-resident dendritic cells take up exogenous and self-antigens released from damaged cells and promote type 2 immunity. CD8 + T cells infiltrate atopic dermatitis skin and activate Th2 cells to further release IL-4 and IL-13, which promotes IgE class switching. Cytokines released from skin infiltrating Th17 and Th22 lymphocytes synergize, leading to further barrier impairment and epidermal hyperplasia. DC, dendritic cell; FLG, Filaggrin; Ig, immunoglobulin; IL, interleukin; ILC2, type 2 innate lymphoid cells; INV, Involucrin; LC, Langerhans cell; LOR, Loricrin; OSM, Oncostatin M; OSMR $\beta$, Oncostatin M receptor $\beta$; Th, T helper; TSLP, thymic stromal lymphopoietin. 
TABLE 2 | Summary of JAK inhibitor use in the treatment of dermatologic conditions.

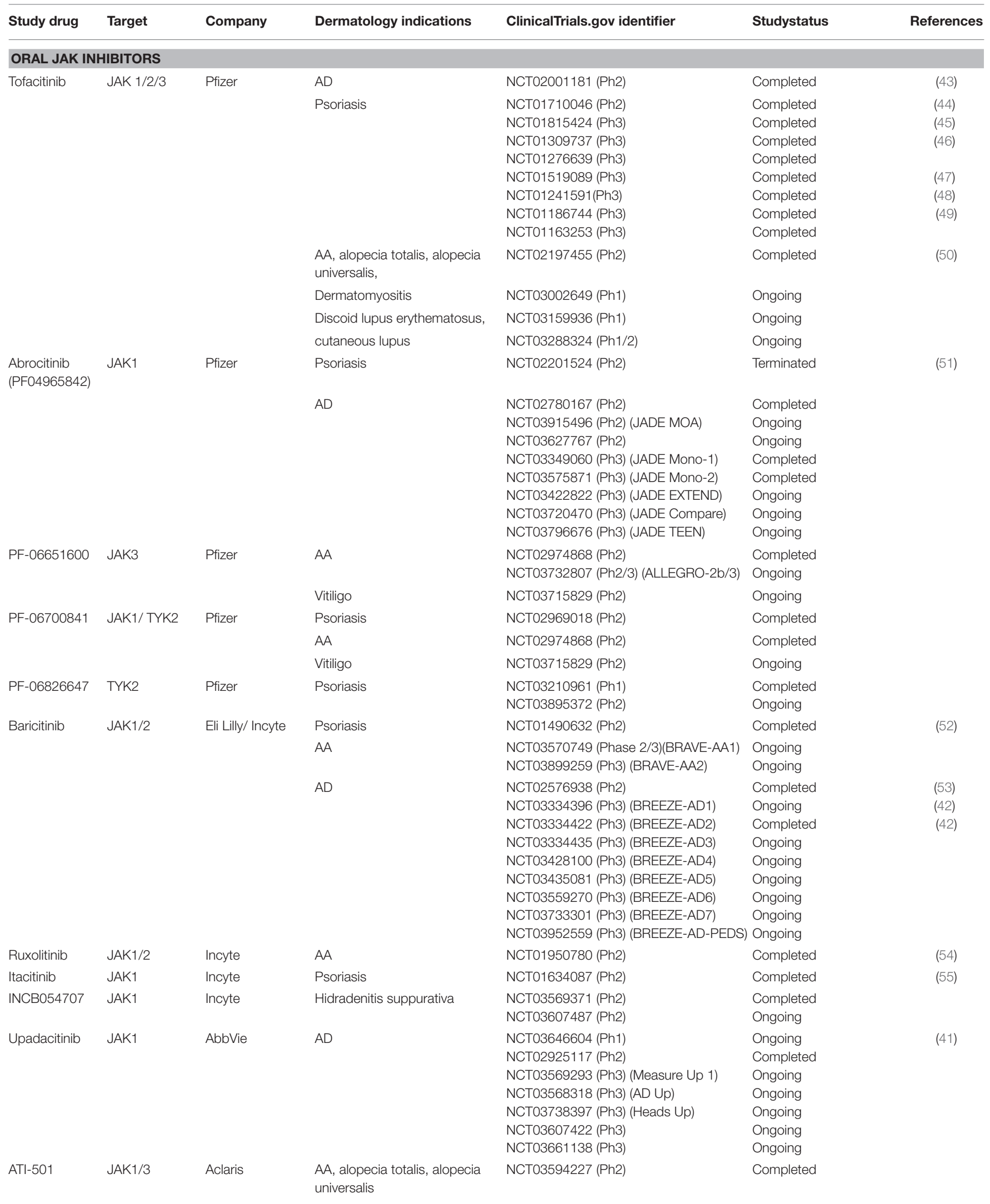


TABLE 2 | Continued

\begin{tabular}{|c|c|c|c|c|c|c|}
\hline Study drug & Target & Company & Dermatology indications & ClinicalTrials.gov identifier & Studystatus & References \\
\hline \multicolumn{7}{|c|}{ ORAL JAK INHIBITORS } \\
\hline \multirow[t]{2}{*}{ ASNOO2 } & $\begin{array}{l}\text { JAK1/2/3 Tyk2 } \\
\text { SYK }\end{array}$ & $\begin{array}{l}\text { Asana } \\
\text { BioSciences }\end{array}$ & $A D$ & $\begin{array}{l}\text { NCT03139981 (Ph1) } \\
\text { NCT03654755 (Ph2) } \\
\text { NCT03531957 (Ph2) (RADIANT) }\end{array}$ & $\begin{array}{l}\text { Completed } \\
\text { Ongoing } \\
\text { Ongoing }\end{array}$ & (56) \\
\hline & & & Chronic hand eczema & NCT03728504 (Ph2) & Ongoing & \\
\hline Filgotinib & JAK1 & Galapagos NV & Cutaneous lupus & NCT03134222 (Ph2) & Ongoing & \\
\hline BMS-986165 & TYK2 & BMS & Psoriasis & $\begin{array}{l}\text { NCT03004768 (Ph1) } \\
\text { NCT02931838 (Ph2) } \\
\text { NCT03924427 (Ph3) } \\
\text { NCT03624127 (Ph3) (POETYK-PSO-1) } \\
\text { NCT03611751 (Ph3) (POETYK-PSO-2) }\end{array}$ & $\begin{array}{l}\text { Completed } \\
\text { Completed } \\
\text { Ongoing } \\
\text { Ongoing } \\
\text { Ongoing }\end{array}$ & (57) \\
\hline Lestaurtinib & JAK2 & Teva/Cephalon & Psoriasis & NCT00236119 (Ph2) & Completed & \\
\hline Study drug & Target & Manufacture & Dermatology indications & ClinicalTrials.gov identifier & & \\
\hline \multicolumn{7}{|c|}{ TOPICAL JAK INHIBITORS } \\
\hline \multirow[t]{3}{*}{ Tofacitinib } & $\mathrm{JAK} 1 / 2 / 3$ & Pfizer & Psoriasis & $\begin{array}{l}\text { NCT01831466 (Ph2) } \\
\text { NCT01246583 (Ph2) }\end{array}$ & $\begin{array}{l}\text { Completed } \\
\text { Completed }\end{array}$ & $\begin{array}{l}(59) \\
(60)\end{array}$ \\
\hline & & & $A D$ & NCT02001181 (Ph2) & Completed & (43) \\
\hline & & & AA & NCT02812342 (Ph2) & Completed & (61) \\
\hline \multirow[t]{2}{*}{ PF-06700841 } & JAK1/ TYK2 & Pfizer & Psoriasis & NCT03850483 (Ph2) & Ongoing & \\
\hline & & & $A D$ & NCT03903822 (Ph2) & Ongoing & \\
\hline & & & Vitiligo & $\begin{array}{l}\text { NCT03099304 (Ph2) } \\
\text { NCT02809976 (Ph2) }\end{array}$ & $\begin{array}{l}\text { Ongoing } \\
\text { Completed }\end{array}$ & $(66,67)$ \\
\hline \multirow{4}{*}{$\begin{array}{l}\text { ATI-502 } \\
\text { (ATI-50002) }\end{array}$} & JAK1/3 & Aclaris & $A D$ & NCT03585296 (Ph2) & Completed & \\
\hline & & & $\begin{array}{l}\text { AA, alopecia totalis, alopecia } \\
\text { universalis }\end{array}$ & $\begin{array}{l}\text { NCT03315689 (Ph2-AU and AT) } \\
\text { NCT03551821 (Ph2-eyebrow) } \\
\text { NCT03354637 (Ph2) } \\
\text { NCT03759340 (Ph2) }\end{array}$ & $\begin{array}{l}\text { Completed } \\
\text { Completed } \\
\text { Ongoing } \\
\text { Ongoing }\end{array}$ & \\
\hline & & & Androgenetic alopecia & NCT03495817 (Ph2) & Ongoing & \\
\hline & & & Vitiligo & NCT03468855 (Ph2) & Ongoing & \\
\hline \multirow[t]{4}{*}{$\begin{array}{l}\text { Delgocitinib } \\
\text { (JTE-052) }\end{array}$} & $\begin{array}{l}\text { JAK1/2/3 Tyk } \\
\text { Syk }\end{array}$ & $\begin{array}{l}\text { Japan Tobacco } \\
\text { Inc.; Leo }\end{array}$ & $A D$ & $\begin{array}{l}\text { NCT03826901 (Ph1) } \\
\text { NCT03725722 (Ph2) (mild to severe AD) }\end{array}$ & $\begin{array}{l}\text { Ongoing } \\
\text { Ongoing }\end{array}$ & \\
\hline & & & Chronic hand eczema & NCT03683719 (Ph2) & Ongoing & \\
\hline & & & AA & $\begin{array}{l}\text { NCT02561585 (Ph2) } \\
\text { NCT03325296 (Ph2-eyebrow) }\end{array}$ & $\begin{array}{l}\text { Completed } \\
\text { Terminated }\end{array}$ & \\
\hline & & & Discoid lupus & NCT03958955 (Ph2) & Ongoing & \\
\hline
\end{tabular}

AA, alopecia areata; $A D$, atopic dermatitis; JAK, Janus kinase; TYK, tyrosine kinase. 


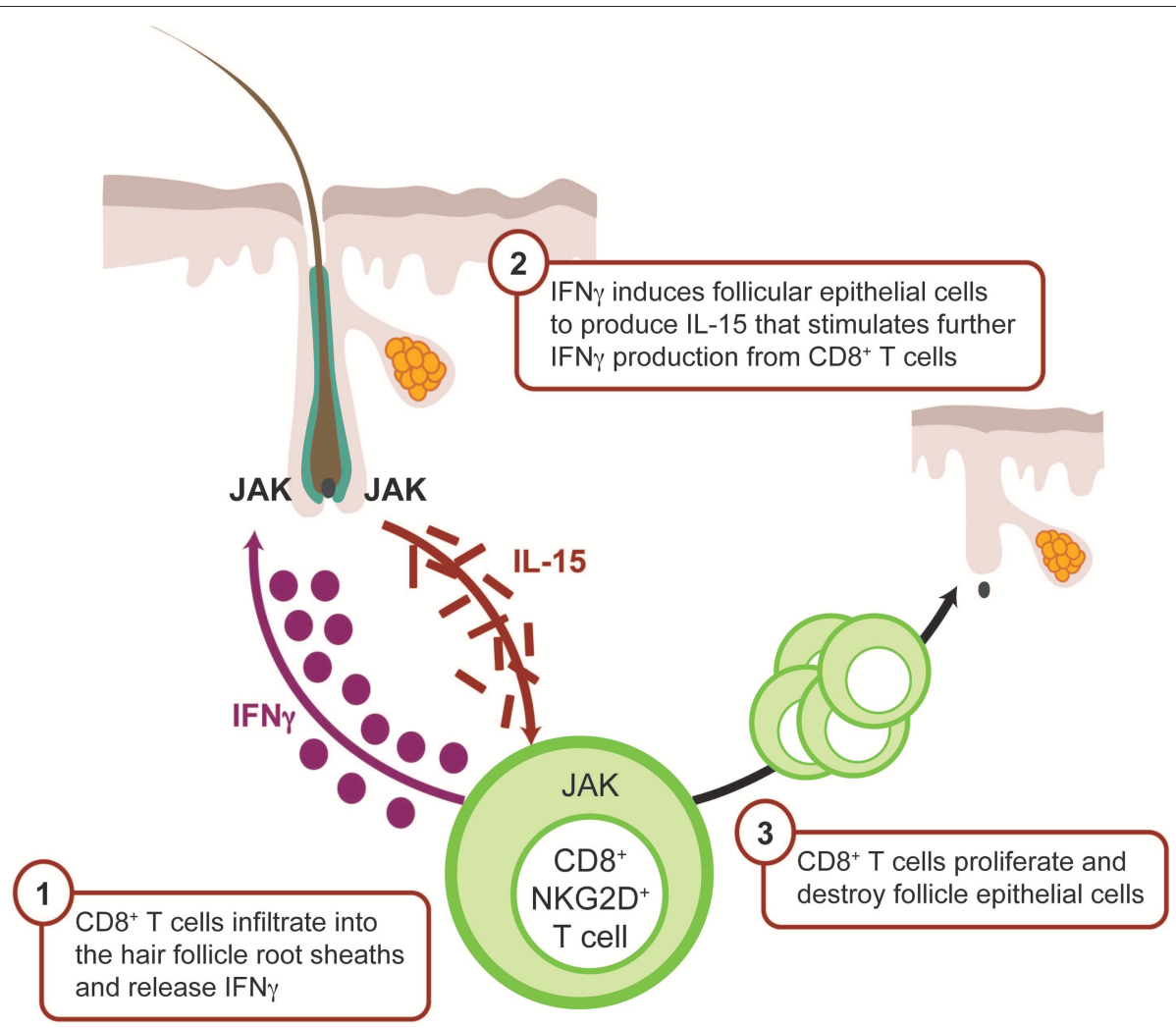

FIGURE 4 | IFN $\gamma$-driven inflammation in alopecia areata is JAK mediated. CD8 ${ }^{+} \mathrm{T}$ cells infiltrate the dermis, localize to the hair follicle bulb, and release IFN $\gamma$. IFN $\gamma$ binds the IFN receptor on the surface of the follicular epithelial cell, which in turn signals via JAK1 and JAK2 to promote production of IL-15, a mediator of CD ${ }^{+}$T-cell activation. IL-15 binds IL-15 receptor on the CD8 ${ }^{+} \mathrm{T}$ cell surface, resulting in signaling via JAK1 and JAK3 to enhance the production of IFN $\gamma$ and amplify the feedback loop. CD8 ${ }^{+}$T cells then attack the hair follicle, which causes hair loss. CXCL, chemokine (C-X-C motif) ligand; IFN, interferon; JAK, Janus kinase.

Areata Disease Activity Index (ALADIN) IFN $\gamma$ gene expression signature (80). Topical administration of JAK inhibitors reversed AA in $\mathrm{C} 3 \mathrm{H} / \mathrm{HeJ}$ mice (81); however, murine skin is significantly thinner and easier to penetrate, and, therefore the translational validity of these data is still unknown. In addition to its proinflammatory activity, IFN $\gamma$-induced JAK/STAT signaling and the recruitment of $\mathrm{CD}^{+} \mathrm{T}$ cells through CXCL9 and CXCL10 can directly interfere with the hair growth cycle via suppressed proliferation and activation of hair stem cells (97) and reduction of angiogenesis (98).

Several case studies have reported improvement of AA in patients who received JAK inhibitors for other autoimmune/autoinflammatory disorders or JAK-STAT gain-of-function mutation diseases (99-103).

Oral tofacitinib has been tested in two open-label studies (NCT02197455 and NCT02312882) and several case reports. In one trial, tofacitinib $5 \mathrm{mg}$ twice daily (BID) was given to patients with severe AA, alopecia totalis, or alopecia universalis. After the 12-week treatment period, nearly twothirds of patients showed some hair regrowth and 32\% of patients achieved a 50\% improvement in their Severity of Alopecia Tool (SALT) score (50). The second smaller openlabel study in moderate to severe AA demonstrated improved results by increasing the dose of tofacitinib to $10 \mathrm{mg}$ BID
(104). Recently, two retrospective studies showed successful treatment of severe AA, alopecia totalis, or alopecia universalis for up to 18 months using tofacitinib, with 58\% achieving a $50 \%$ improvement $20 \%$ achieving a $90 \%$ improvement in their SALT score (105-107). Oral ruxolitinib was tested in an open-label study in 12 patients with moderate to severe AA and treatment with $20 \mathrm{mg}$ ruxolitinib BID for 6 months was associated with $\geq 50 \%$ improvement in SALT score for $75 \%$ of patients (NCT01950780) (54). Regrowth was seen, in patches as soon as 1 month after study medication was initiated. Following cessation of treatment, shedding was observed, suggesting that pharmacologic JAK inhibition suppresses AA pathogenesis but does deplete autoreactive lymphocytes. Topical formulations of ruxolitinib, tofacitinib, ATI-502 (JAK1/3), and delgocitinib have reported mixed efficacy results in case studies and small proofof-concept clinical trials $(61,108,109)$. At present, there are several clinical trials testing topical JAK inhibitors in patients with different forms of AA, but published results are not yet available (Table 2).

\section{PSORIASIS}

Psoriasis is a chronic, autoimmune, erythematosquamous dermatosis disorder that affects 2 to $3 \%$ of the world 
population. Skin lesions appear with scaling and redness (110) and are characterized by excessive keratinocyte proliferation (acanthosis), as well as retention of nuclei in the stratum corneum owing to aberrant keratinocyte differentiation (parakeratosis). Multiple inflammatory cell populations are observed within the lesions, including T cells, B cells, neutrophils, and DCs (110). Infiltrating autoreactive $\mathrm{T}$ lymphocytes, mainly represented by Th17, Th1, and Th22 cells, release IL-17, IFN $\gamma$, IL-22, and TNF $\alpha$ to potentiate disease pathogenesis. All of these cytokines induce keratinocyte-mediated recruitment and activation of additional DCs and lymphocytes, thereby perpetuating the pathogenic cycle $(111,112)$.

Many of the critical pathogenic mediators of psoriasis are linked to the JAK-STAT signaling pathway. For example, IL23 engagement with its cognate receptor uses JAK1/2/TYK2 signaling, resulting in downstream STAT3 and STAT4 activation. Within psoriatic skin, dendritic cells and macrophages produce IL-23, which promotes Th17 cell expansion and survival (113). Furthermore, IL-23 together with IL-1 $\beta$ activates $\gamma \delta \mathrm{T}$ cells to amplify IL-17 production (114). Th17 and $\gamma \delta$ T cells found in psoriatic skin are the primary source of IL-22, and this cytokine triggers reduced differentiation, increased proliferation, and acanthosis in psoriatic keratinocytes via STAT3 activation (115). IL-22 binds to its IL-10R2 and IL-22R1 heterodimeric cell surface receptor coupled to JAK1/TYK2 and STAT3 signaling $(111,116)$. Moreover, gene polymorphisms of IL23A, IL23R, STAT3, RUNX3, and TYK2 have also been identified as susceptibility factors for developing psoriasis (117). More recently, JAK1 expression has been reported to positively correlate with disease duration and Psoriasis Area and Severity Index (PASI) (118) score. Within the inflamed tissue psoriatic lesion microenvironment, other cytokines, such as IL-6 and IL-21, can enhance IL-17 production from Th17 cells in a JAK-STAT-dependent manner $(119,120)$.

Various rodent models have mechanistically evaluated the importance of JAK-STAT signaling in psoriasis-like lesion formation and disrupted barrier function. Intradermal injection of IL-23 induces a psoriasis-like pathophysiology in mice (121). Oral administration of delgocitinib or topical administration of ruxolitinib significantly inhibited ear swelling $(29,122)$, and efficacy was associated with reduced IL-22 expression (29). Tofacitinib, modulates both innate and adaptive immunity leading to inhibited pathogenic Th17 cell differentiation via reduced IL-23 expression (123). In human keratinocyte cultures activated with psoriasis-relevant proinflammatory cytokines, tofacitinib suppressed expression of IFN $\gamma$-dependent inflammatory genes and normalized keratinocyte responses. Similarly, in the imiquimod-induced psoriasis model that is IL-23/IL-17/IL-22-dependent (121), tofacitinib significantly reduced epidermal thickening and $\mathrm{IL}-17^{+}$or IL- $22^{+}$lymphocyte infiltration into the dermis (124). Furthermore, a small molecule JAK3 / SYK inhibitor (R348, Rigel Pharmaceuticals), attenuated T-cell-dependent psoriasiform skin lesions in the CD18 mutant $\mathrm{PL} / \mathrm{J}$ mouse model, including significant reductions in epidermal and dermal lesion scores (125). In T cells, IL-12 induces IFN $\gamma$ production, IL-23 enhances the differentiation of Th17 cells, and both require TYK2 signaling $(126,127)$. TYK2 knockout reduced inflammatory response and limited epidermal hyperplasia in the intradermal IL-23 model (128). Furthermore, TYK2-deficient mice were more resistant to several Th1 and Th17 cells autoimmune disorders, including imiquimod-induced psoriasislike dermatitis (128). The combined JAK1/TYK2 inhibitor, SAR-20347, demonstrated in vitro and in vivo concentrationdependent reduction of IL-12, IL-22, and IFN $\gamma$-mediated inflammation and tissue pathology in the imiquimod-induced psoriasis model (129). Finally, experimentally induced skin trauma in the keratin5.Stat3C transgenic mice (130), which constitutively overexpresses active STAT3 in keratinocytes, develops T-cell- and IL-23-dependent psoriasis-like lesions. Topical administration of a STAT3 inhibitor prevented disease symptoms (130-132). These preclinical findings are consistent with the postulate that the JAK-STAT pathway plays a central role in psoriasis pathogenesis.

Clinically, the efficacy of oral tofacitinib in moderate to severe plaque psoriasis was demonstrated in two phase 3 randomized controlled trials (46). Tofacitinib at $10 \mathrm{mg}$ BID was determined to be non-inferior to etanercept ( $50 \mathrm{mg}$ subcutaneously twice weekly) (47). Baricitinib was reported to be efficacious in moderate to severe psoriasis in a phase 2 trial (NCT01490632). In this 12 -week dose-ranging study, a $75 \%$ reduction in PASI was achieved by $43 \%$ and $54 \%$ of patients treated with baricitinib 8 and $10 \mathrm{mg}$ QD, respectively (52). Itacitinib (JAK1) was evaluated in a phase 2 dose-escalation study in which patients experienced a significant improvement in the Physician Global Assessment (PGA) score at Week 4 with itacitinib $600 \mathrm{mg}$ QD vs. placebo (NCT01634087) (55). Peficitinib (JAK1/3) reported improvements in PASI, PGA, and body surface area at higher dose (50 mg QD) at Day 42 in a phase 2 study (58). In another phase 2 study, $57 \%$ of patients treated with GSK2586184 (JAK1) $400 \mathrm{mg}$ QD achieved a 75\% reduction in PASI at Week 12 (133).

Topical tofacitinib has been tested in patients with psoriasis, with conflicting results $(52,60,134)$. Three psoriasis clinical trials have been completed using topical ruxolitinib cream. In a phase 2 vehicle-controlled study in mild to moderate psoriasis (NCT00778700), ruxolitinib reported PASI reduction, although no clear dose-response was observed. A subsequent trial in 29 patients with psoriasis compared ruxolitinib cream to two active comparators (calcipotriene $0.005 \%$ cream and betamethasone dipropionate $0.05 \%$ cream; NCT00820950). Both ruxolitinib 1\% QD and 1.5\% BID achieved clinical efficacy, with $1.5 \%$ BID topical ruxolitinib cream being non-inferior to active comparators (62). Finally, a third study conducted in 25 patients with limited psoriasis (covering $<20 \%$ of the body surface area; NCT00617994) showed that epidermal hyperplasia and dermal inflammation were reduced with ruxolitinib in most patients, along with immunohistochemical markers of inflammation (CD3, CD11c, Ki67, and K16). No significant inhibition of phosphorylated STAT3 in peripheral blood cells was observed, suggesting limited systemic exposure (63). A number of other JAK inhibitors have been studied in psoriasis (Table 2).

\section{VITILIGO}

Vitiligo is a chronic, autoimmune depigmenting disorder that results from destruction of melanocytes, causing white spots on the affected skin. The global vitiligo prevalence is $\sim 0.5$ to $2.0 \%$ and varies geographically, with no epidemiologic differences 


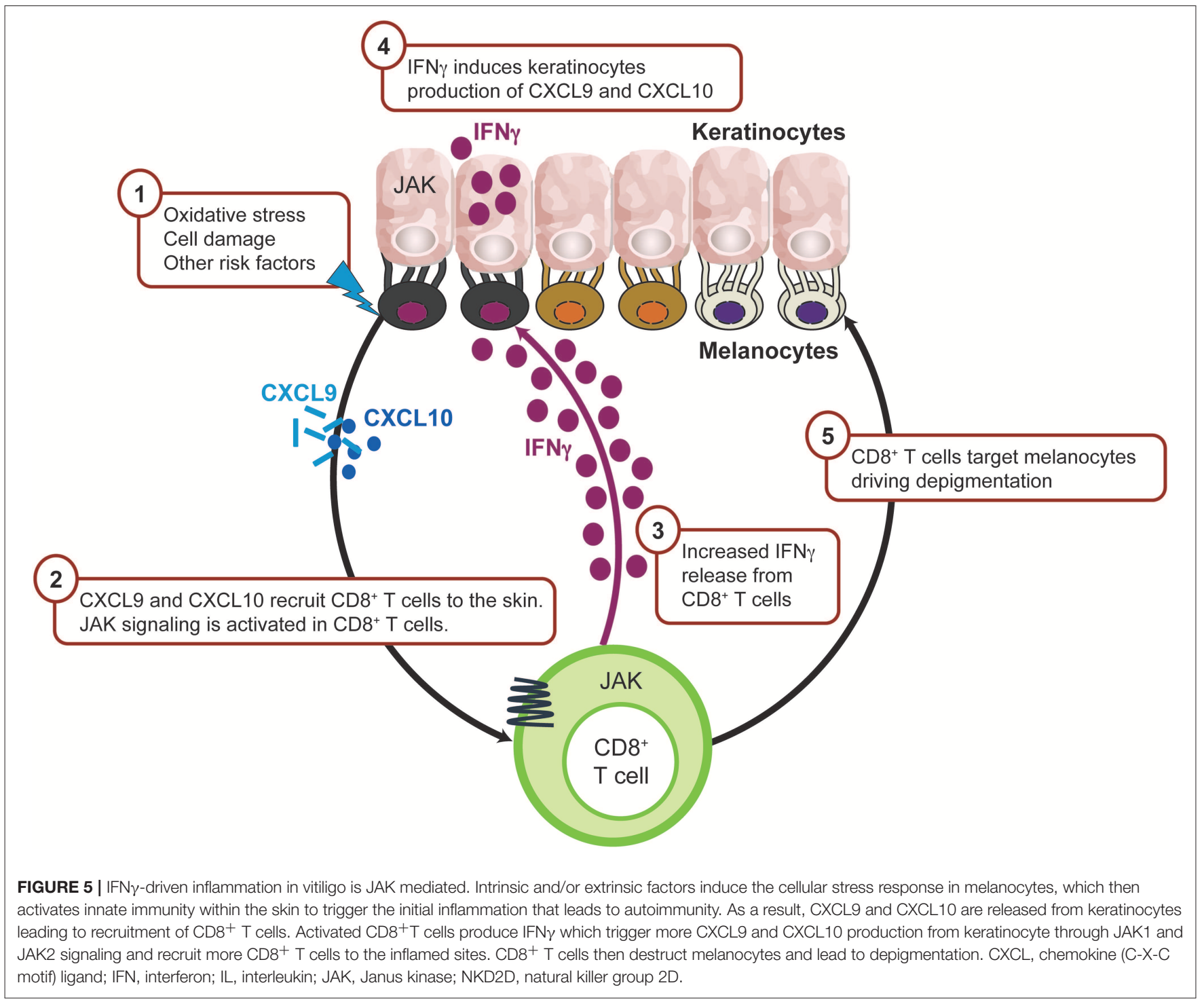

between sexes or races $(135,136)$. Vitiligo can be stigmatized by society, resulting in a significant impact to patient quality of life $(137,138)$. It is therefore inappropriate to categorize vitiligo as simply a cosmetic problem.

In vitiligo, the frequency of anti-melanocyte $\mathrm{CD}^{+} \mathrm{T}$ cells in the blood and skin correlates with disease severity, and lesional $\mathrm{CD}^{+} \mathrm{T}$ cells in vitro induce melanocyte apoptosis in unaffected skin $(139,140)$. These data support the rationale that cytotoxic $\mathrm{T}$ lymphocytes are directly responsible for melanocyte destruction in human vitiligo (Figure 5). Expression analysis reveals an IFN $\gamma$-specific signature that is associated with infiltrating autoreactive $\mathrm{CD}^{+} \mathrm{T}$ cells $(140,141)$. Transcriptome analysis on the skin and blood of patients with vitiligo revealed IFN $\gamma$-induced chemokines CXCL10 and CXCL9 were increased (142, 143), which is consistent with the observed abundance of autoreactive $\mathrm{T}$ cells expressing the cognate CXCR3 receptor (144). Furthermore, serum CXCL10 levels were associated with Vitiligo Area Scoring Index (VASI) of patients with progressive vitiligo, suggesting that the CXCL10/CXCR3 axis mediates T-cell recruitment into the skin of progressive vitiligo.

Consistent with active human vitiligo reports, an adoptive transfer of melanocyte-specific $\mathrm{CD}^{+}$mouse model shows epidermal depigmentation but sparing of the hair follicle. Mechanistic studies, including neutralizing antibodies, have demonstrated that depigmentation is IFN $\gamma$-dependent via the local accumulation of melanocyte-specific $\mathrm{CD}^{+} \mathrm{T}$ cells within the skin. Adoptive transfer of CXCR3-deficient $\mathrm{T}$ cells or inhibition of CXCL10 signaling ameliorated overall disease phenotype, whereas CXCL9 promoted autoreactive T-cell recruitment to the skin but did not significantly contribute to effector function $(141,145)$. Keratinocytes appear to significantly contribute to the disease process as major chemokine producers via IFN signaling, resulting in augmented autoreactive T-cell homing to the epidermis (146).

Given the apparent critical role for IFN $\gamma$ in driving vitiligo inflammation and its downstream signaling dependent on 
the JAK1-JAK2 heterodimer, it is perhaps not surprising that intense and diffuse JAK1 expression is more present within vitiliginous skin compared with healthy tissue. Moreover, high JAK1 expression was associated with short disease duration and a lower percentage of surviving melanocytes (118, 147, 148).

Multiple case reports suggested that orally administered JAK inhibition significantly modulated the vitiligo autoimmune response and facilitated repigmentation (102, 108, 149). Another possible approach to diminish local inflammation and promote repigmentation in vitiligo, but minimize systemic drug exposures, is the use of topical JAK inhibitors. Recently, Rothstein et al. reported a very small open-label trial without placebo control (NCT02809976) in which nine patients completed the 20 week study period. Twice daily ruxolitinib cream demonstrated time-dependent improvement in facial VASI (F-VASI) in the majority of the enrolled vitiligo patients (67). Recently, ruxolitinib cream was tested in a randomized, double-blinded, dose-ranging, vehicle-controlled, phase 2 study in 157 adult patients with vitiligo (NCT03099304). The results show that significantly more patients treated with ruxolitinib cream for 24 weeks achieved a $\geq 50 \%$ percent improvement from baseline in the facial VASI score compared with patients treated with a control vehicle [(66); World Congress of Dermatology; June 2019; Milan, Italy].

\section{CONCLUSIONS}

Despite phenotypic differences in the inflammatory mediators responsible for driving disease pathogenesis, these aforementioned dermatoses are characterized by increased inflammatory mediators that signal through the JAK-STAT pathway.

JAK inhibitors are emerging as an exciting class of treatments in the field of dermatology. In murine models of skin inflammation, JAK inhibitors significantly modulated key mechanistic phenotypes that correspond with clinical

\section{REFERENCES}

1. Villarino AV, Kanno Y, O'shea JJ. Mechanisms and consequences of JakSTAT signaling in the immune system. Nat Immunol. (2017) 18:374-84. doi: $10.1038 /$ ni.3691

2. Rawlings JS, Rosler KM, Harrison DA. The JAK/STAT signaling pathway. J Cell Sci. (2004) 117:1281-3. doi: 10.1242/jcs.00963

3. Howell MD, Fitzsimons C, Smith PA. JAK/STAT inhibitors and other small molecule cytokine antagonists for the treatment of allergic disease. Ann Allergy Asthma Immunol. (2018) 120:367-75. doi: 10.1016/j.anai.2018.02.012

4. Stark GR, Cheon H, Wang Y. Responses to cytokines and interferons that depend upon JAKs and STATs. Cold Spring Harb Perspect Biol. (2018) 10:a028555. doi: 10.1101/cshperspect.a028555

5. Maldonado RA, Soriano MA, Perdomo LC, Sigrist K, Irvine DJ, Decker $\mathrm{T}$, et al. Control of $\mathrm{T}$ helper cell differentiation through cytokine receptor inclusion in the immunological synapse. J Exp Med. (2009) 206:877-92. doi: 10.1084/jem.20082900

6. Mowen KA, Glimcher LH. Signaling pathways in Th2 development. Immunol Rev. (2004) 202:203-22. doi: 10.1111/j.0105-2896.2004.00209.x readouts, such as acanthosis and pruritus. Early phase clinical reports confirmed the positive concept of JAK-STAT antagonism in dermatology, and randomized clinical trials have shown promising results in $\mathrm{AD}$, psoriasis, and vitiligo. Encouraging data were observed in a proportion of AA participants; however, additional studies are needed to fully elucidate the disease pathophysiology and the role for JAK-STAT inhibition.

Larger clinical studies of oral and topical JAK inhibitors in AD, psoriasis, and vitiligo are currently ongoing. These pivotal trials are expected to provide additional insight into the efficacy and safety of JAK inhibitors in dermatology. Safety information for Jakinibs in inflammatory disease indications is mostly based on randomized clinical trials for investigational uses and extension studies. Recent, comprehensive, summaries of the key laboratory changes and clinical adverse events have been reported $(150,151)$.

Based on the promising results so far and the large number of ongoing clinical trials, it is possible that JAK inhibitors will become an important part of the dermatologist's treatment armamentarium in the future.

\section{AUTHOR CONTRIBUTIONS}

All authors listed have made a substantial, direct and intellectual contribution to the work, and approved it for publication.

\section{FUNDING}

The authors declare that this study received funding from Incyte Corporation. The funder was not involved in the study design, collection, analysis, interpretation of data, the writing of this article or the decision to submit it for publication.

\section{ACKNOWLEDGMENTS}

Editorial and graphical support was provided by Complete Healthcare Communications (North Wales, PA) and was funded by Incyte Corporation.
7. Chen Z, Laurence A, O'shea JJ. Signal transduction pathways and transcriptional regulation in the control of Th17 differentiation. Semin Immunol. (2007) 19:400-8. doi: 10.1016/j.smim.2007.10.015

8. O'shea JJ, Steward-Tharp SM, Laurence A, Watford WT, Wei L, Adamson AS, et al. Signal transduction and Th17 cell differentiation. Microbes Infect. (2009) 11:599-611. doi: 10.1016/j.micinf.2009.04.007

9. Wuthrich B, Schmid-Grendelmeier P. The atopic eczema/dermatitis syndrome. Epidemiology, natural course, and immunology of the IgEassociated ("extrinsic") and the nonallergic ("intrinsic"). AEDS J Investig Allergol Clin Immunol. (2003) 13:1-5. doi: 10.3109/9780203908877-2

10. Deckers IA, Mclean S, Linssen S, Mommers M, Van Schayck CP, Sheikh A. Investigating international time trends in the incidence and prevalence of atopic eczema 1990-2010: a systematic review of epidemiological studies. PLoS ONE. (2012) 7:e39803. doi: 10.1371/journal.pone.0039803

11. Zuberbier T, Orlow SJ, Paller AS, Taieb A, Allen R, Hernanz-Hermosa JM, et al. Patient perspectives on the management of atopic dermatitis. J Allergy Clin Immunol. (2006) 118:226-32. doi: 10.1016/j.jaci.2006.02.031

12. Wollenberg A, Oranje A, Deleuran M, Simon D, Szalai Z, Kunz B, et al. ETFAD/EADV Eczema task force 2015 position paper on diagnosis and 
treatment of atopic dermatitis in adult and paediatric patients. J Eur Acad Dermatol Venereol. (2016) 30:729-47. doi: 10.1111/jdv.13599

13. Thyssen JP, Hamann CR, Linneberg A, Dantoft TM, Skov L, Gislason GH, et al. Atopic dermatitis is associated with anxiety, depression, and suicidal ideation, but not with psychiatric hospitalization or suicide. Allergy. (2018) 73:214-20. doi: 10.1111/all.13231

14. Hebert AA, Stingl G, Ho LK, Lynde C, Cappelleri JC, Tallman AM, et al. Patient impact and economic burden of mild-to-moderate atopic dermatitis. Curr Med Res Opin. (2018) 34:2177-85. doi: 10.1080/03007995.2018.1498329

15. Weidinger S, Novak N. Atopic dermatitis. Lancet. (2016) 387:1109-22. doi: 10.1016/S0140-6736(15)00149-X

16. Neis MM, Peters B, Dreuw A, Wenzel J, Bieber T, Mauch C, et al. Enhanced expression levels of IL-31 correlate with IL-4 and IL-13 in atopic and allergic contact dermatitis. J Allergy Clin Immunol. (2006) 118:930-7. doi: 10.1016/j.jaci.2006.07.015

17. Amano W, Nakajima S, Yamamoto Y, Tanimoto A, Matsushita M, Miyachi Y, et al. JAK inhibitor JTE-052 regulates contact hypersensitivity by downmodulating $\mathrm{T}$ cell activation and differentiation. J Dermatol Sci. (2016) 84:258-65. doi: 10.1016/j.jdermsci.2016.09.007

18. Jin W, Huang W, Chen L, Jin M, Wang Q, Gao Z, et al. Topical application of JAK1/JAK2 inhibitor momelotinib exhibits significant anti-inflammatory responses in DNCB-induced atopic dermatitis model mice. Int J Mol Sci. (2018) 19:3973. doi: 10.3390/ijms19123973

19. Fukuyama T, Ehling S, Cook E, Baumer W. Topically administered januskinase inhibitors tofacitinib and oclacitinib display impressive antipruritic and anti-inflammatory responses in a model of allergic dermatitis. $J$ Pharmacol Exp Ther. (2015) 354:394-405. doi: 10.1124/jpet.115.223784

20. Fujii Y, Sengoku T. Effects of the Janus kinase inhibitor CP- 690550 (tofacitinib) in a rat model of oxazolone-induced chronic dermatitis. Pharmacology. (2013) 91:207-13. doi: 10.1159/000347184

21. Boniface K, Bernard FX, Garcia M, Gurney AL, Lecron JC, Morel F. IL22 inhibits epidermal differentiation and induces proinflammatory gene expression and migration of human keratinocytes. J Immunol. (2005) 174:3695-702. doi: 10.4049/jimmunol.174.6.3695

22. Lou H, Lu J, Choi EB, Oh MH, Jeong M, Barmettler S, et al. Expression of IL22 in the Skin Causes Th2-Biased Immunity, Epidermal Barrier Dysfunction, and Pruritus via Stimulating Epithelial Th2 Cytokines and the GRP Pathway. J Immunol. (2017) 198:2543-55. doi: 10.4049/jimmunol.1600126

23. Guttman-Yassky E, Brunner PM, Neumann AU, Khattri S, Pavel AB, Malik $\mathrm{K}$, et al. Efficacy and safety of fezakinumab (an IL-22 monoclonal antibody) in adults with moderate-to-severe atopic dermatitis inadequately controlled by conventional treatments: a randomized, double-blind, phase 2a trial. J Am Acad Dermatol. (2018) 78:872-81 e876. doi: 10.1016/j.jaad.2018. 01.016

24. Lejeune D, Dumoutier L, Constantinescu S, Kruijer W, Schuringa JJ, Renauld JC. Interleukin-22 (IL-22) activates the JAK/STAT, ERK, JNK, and p38 MAP kinase pathways in a rat hepatoma cell line. Pathways that are shared with and distinct from IL-10. J Biol Chem. (2002) 277:33676-82. doi: $10.1074 /$ jbc.M204204200

25. Klonowska J, Glen J, Nowicki RJ, Trzeciak M. New cytokines in the pathogenesis of atopic dermatitis-new therapeutic targets. Int J Mol Sci. (2018) 19:E3086. doi: 10.3390/ijms19103086

26. Zhang Q, Putheti P, Zhou Q, Liu Q, Gao W. Structures and biological functions of IL-31 and IL-31 receptors. Cytokine Growth Factor Rev. (2008) 19:347-56. doi: 10.1016/j.cytogfr.2008.08.003

27. Zhong J, Sharma J, Raju R, Palapetta SM, Prasad TS, Huang TC, et al. TSLP signaling pathway map: a platform for analysis of TSLP-mediated signaling. Database. (2014) 2014:bau007. doi: 10.1093/database/bau007

28. Gonzales AJ, Bowman JW, Fici GJ, Zhang M, Mann DW, Mitton-Fry M. Oclacitinib (APOQUEL ${ }^{\circledR}$ ) is a novel Janus kinase inhibitor with activity against cytokines involved in allergy. J Vet Pharmacol Ther. (2014) 37:31724. doi: 10.1111/jvp.12101

29. Fridman JS, Scherle PA, Collins R, Burn T, Neilan CL, Hertel D, et al. Preclinical evaluation of local JAK1 and JAK2 inhibition in cutaneous inflammation. J Invest Dermatol. (2011) 131:1838-44. doi: $10.1038 /$ jid.2011.140

30. Leyva-Castillo JM, Hener P, Jiang H, Li M. TSLP produced by keratinocytes promotes allergen sensitization through skin and thereby triggers atopic march in mice. J Invest Dermatol. (2013) 133:154-63. doi: $10.1038 /$ jid.2012.239

31. Oetjen LK, Mack MR, Feng J, Whelan TM, Niu H, Guo CJ, et al. Sensory neurons co-opt classical immune signaling pathways to mediate chronic itch. Cell. (2017) 171:217-28 e213. doi: 10.1016/j.cell.2017.08.006

32. Kim BE, Leung DY, Boguniewicz M, Howell MD. Loricrin and involucrin expression is down-regulated by Th2 cytokines through STAT-6. Clin Immunol. (2008) 126:332-7. doi: 10.1016/j.clim.2007.11.006

33. Albanesi C, Fairchild HR, Madonna S, Scarponi C, De Pita O, Leung DY, et al. IL-4 and IL-13 negatively regulate TNF-alpha- and IFNgamma-induced beta-defensin expression through STAT-6, suppressor of cytokine signaling (SOCS)-1, and SOCS-3. J Immunol. (2007) 179:984-92. doi: 10.4049/jimmunol.179.2.984

34. Sehra S, Yao Y, Howell MD, Nguyen ET, Kansas GS, Leung DY, et al. IL-4 regulates skin homeostasis and the predisposition toward allergic skin inflammation. J Immunol. (2010) 184:3186-90. doi: 10.4049/jimmunol.0901860

35. Yasuda T, Fukada T, Nishida K, Nakayama M, Matsuda M, Miura I, et al. Hyperactivation of JAK1 tyrosine kinase induces stepwise, progressive pruritic dermatitis. J Clin Invest. (2016) 126:2064-76. doi: 10.1172/JCI82887

36. Amano W, Nakajima S, Kunugi H, Numata $Y$, Kitoh A, Egawa G, et al. The Janus kinase inhibitor JTE-052 improves skin barrier function through suppressing signal transducer and activator of transcription 3 signaling. J Allergy Clin Immunol. (2015) 136:667-77 e667. doi: 10.1016/j.jaci.2015.03.051

37. Brauweiler AM, Goleva E, Leung DYM. Th2 cytokines increase Staphylococcus aureus alpha toxin-induced keratinocyte death through the signal transducer and activator of transcription 6 (STAT6). J Invest Dermatol. (2014) 134:2114-21. doi: 10.1038/jid.2014.43

38. Koga C, Kabashima K, Shiraishi N, Kobayashi M, Tokura Y. Possible pathogenic role of Th17 cells for atopic dermatitis. J Invest Dermatol. (2008) 128:2625-30. doi: 10.1038/jid.2008.111

39. Noda S, Suarez-Farinas M, Ungar B, Kim SJ, De Guzman Strong C, Xu H, et al. The Asian atopic dermatitis phenotype combines features of atopic dermatitis and psoriasis with increased TH17 polarization. J Allergy Clin Immunol. (2015) 136:1254-64. doi: 10.1016/j.jaci.2015.08.015

40. Levy LL, Urban J, King BA. Treatment of recalcitrant atopic dermatitis with the oral Janus kinase inhibitor tofacitinib citrate. J Am Acad Dermatol. (2015) 73:395-9. doi: 10.1016/j.jaad.2015.06.045

41. Guttman-Yassky E. Primary results from a phase 2b, randomized, placebocontrolled trial of upadacitinib for patients with atopic dermatitis. In: Presented at: The American Academy of Dermatology (AAD) Annual Meeting, February 16-20. San Diego, CA (2018).

42. Simpson EL, Lacour E-P, Spelman L, Galimberti R, Eichenfield L, Bissonnette $\mathrm{R}$, et al. Efficacy and safety of baricitinib in moderate to severe atopic dermatitis: results of two phase 3 monotherapy randomized, double-blind, placebo-controlled 16-week trials (BREEZE-AD1 and BREEZA-AD2). In: Presented at: The 24th World Congress of Dermatology (WCD). Milan (2019).

43. Bissonnette R, Papp KA, Poulin Y, Gooderham M, Raman M, Mallbris L, et al. Topical tofacitinib for atopic dermatitis: a phase IIa randomized trial. Br J Dermatol. (2016) 175:902-11. doi: 10.1111/bjd.14871

44. Krueger J, Clark JD, Suarez-Farinas M, Fuentes-Duculan J, Cueto I, Wang $\mathrm{CQ}$, et al. Tofacitinib attenuates pathologic immune pathways in patients with psoriasis: a randomized phase 2 study. J Allergy Clin Immunol. (2016) 137:1079-90. doi: 10.1016/j.jaci.2015.12.1318

45. Zhang J, Tsai TF, Lee MG, Zheng M, Wang G, Jin H, et al. The efficacy and safety of tofacitinib in Asian patients with moderate to severe chronic plaque psoriasis: a Phase 3, randomized, double-blind, placebo-controlled study. $J$ Dermatol Sci. (2017) 88:36-45. doi: 10.1016/j.jdermsci.2017.05.004

46. Merola JF, Elewski B, Tatulych S, Lan S, Tallman A, Kaur M. Efficacy of tofacitinib for the treatment of nail psoriasis: two 52-week, randomized, controlled phase 3 studies in patients with moderate-tosevere plaque psoriasis. J Am Acad Dermatol. (2017) 77:79-87 e71. doi: 10.1016/j.jaad.2017.01.053

47. Bachelez H, Van De Kerkhof PC, Strohal R, Kubanov A, Valenzuela F, Lee JH, et al. Tofacitinib versus etanercept or placebo in moderate-to-severe chronic plaque psoriasis: a phase 3 randomised non-inferiority trial. Lancet. (2015) 386:552-61. doi: 10.1016/S0140-6736(14)62113-9 
48. Bissonnette R, Iversen L, Sofen H, Griffiths CE, Foley P, Romiti R, et al. Tofacitinib withdrawal and retreatment in moderate-to-severe chronic plaque psoriasis: a randomized controlled trial. Br J Dermatol. (2015) 172:1395-406. doi: 10.1111/bjd.13551

49. Valenzuela F, Korman NJ, Bissonnette R, Bakos N, Tsai TF, Harper MK, et al. Tofacitinib in patients with moderate-to-severe chronic plaque psoriasis: long-term safety and efficacy in an open-label extension study. Br J Dermatol. (2018) 179:853-62. doi: 10.1111/bjd.16798

50. Kennedy Crispin M, Ko JM, Craiglow BG, Li S, Shankar G, Urban JR, et al. Safety and efficacy of the JAK inhibitor tofacitinib citrate in patients with alopecia areata. JCI Insight. (2016) 1:e89776. doi: 10.1172/jci.insight.89776

51. Schmieder GJ, Draelos ZD, Pariser DM, Banfield C, Cox L, Hodge M, et al. Efficacy and safety of the Janus kinase 1 inhibitor PF-04965842 in patients with moderate-to-severe psoriasis: phase II, randomized, double-blind, placebo-controlled study. Br J Dermatol. (2018) 179:54-62. doi: 10.1111/bjd.16004

52. Papp KA, Menter MA, Raman M, Disch D, Schlichting DE, Gaich C, et al. A randomized phase $2 \mathrm{~b}$ trial of baricitinib, an oral Janus kinase (JAK) 1/JAK2 inhibitor, in patients with moderate-to-severe psoriasis. Br J Dermatol. (2016) 174:1266-76. doi: 10.1111/bjd.14403

53. Guttman-Yassky E, Silverberg JI, Nemoto O, Forman SB, Wilke A, Prescilla R, et al. Baricitinib in adult patients with moderate-to-severe atopic dermatitis: a phase 2 parallel, double-blinded, randomized placebocontrolled multiple-dose study. J Am Acad Dermatol. (2019) 80:913-21 e919. doi: 10.1016/j.jaad.2018.01.018

54. Mackay-Wiggan J, Jabbari A, Nguyen N, Cerise JE, Clark C, Ulerio G, et al. Oral ruxolitinib induces hair regrowth in patients with moderate-to-severe alopecia areata. JCI Insight. (2016) 1:e89790. doi: 10.1172/jci.insight.89790

55. Bissonnette R, Luchi M, Fidelus-Gort R, Jackson S, Zhang H, Flores R, et al. A randomized, double-blind, placebo-controlled, dose-escalation study of the safety and efficacy of INCB039110, an oral janus kinase 1 inhibitor, in patients with stable, chronic plaque psoriasis. J Dermatolog Treat. (2016) 27:332-8. doi: 10.3109/09546634.2015.1115819

56. Bissonnette R, Maari C, Forman S, Bhatia N, Lee M, Fowler J, et al. The oral Janus kinase/spleen tyrosine kinase inhibitor ASN002 demonstrates efficacy and improves associated systemic inflammation in patients with moderateto-severe atopic dermatitis: results from a randomized double-blind placebocontrolled study. Br J Dermatol. (2019). doi: 10.1111/bjd.17932. [Epub ahead of print].

57. Papp K, Gordon K, Thaci D, Morita A, Gooderham M, Foley P, et al. Phase 2 trial of selective tyrosine Kinase 2 inhibition in psoriasis. $N$ Engl J Med. (2018) 379:1313-21. doi: 10.1056/NEJMoa1806382

58. Papp K, Pariser D, Catlin M, Wierz G, Ball G, Akinlade B, et al. A phase 2a randomized, double-blind, placebo-controlled, sequential dose-escalation study to evaluate the efficacy and safety of ASP015K, a novel Janus kinase inhibitor, in patients with moderate-to-severe psoriasis. Br J Dermatol. (2015) 173:767-76. doi: 10.1111/bjd.13745

59. Papp KA, Bissonnette R, Gooderham M, Feldman SR, Iversen L, Soung J, et al. Treatment of plaque psoriasis with an ointment formulation of the Janus kinase inhibitor, tofacitinib: a Phase $2 \mathrm{~b}$ randomized clinical trial. BMC Dermatol. (2016) 16:15. doi: 10.1186/s12895-016-0051-4

60. Ports WC, Khan S, Lan S, Lamba M, Bolduc C, Bissonnette R, et al. A randomized phase $2 \mathrm{a}$ efficacy and safety trial of the topical Janus kinase inhibitor tofacitinib in the treatment of chronic plaque psoriasis. $\mathrm{Br} \mathrm{J}$ Dermatol. (2013) 169:137-45. doi: 10.1111/bjd.12266

61. Liu LY, Craiglow BG, King BA. Tofacitinib $2 \%$ ointment, a topical Janus kinase inhibitor, for the treatment of alopecia areata: a pilot study of 10 patients. J Am Acad Dermatol. (2018) 78:403-4 e401. doi: 10.1016/j.jaad.2017.10.043

62. Punwani N, Scherle P, Flores R, Shi J, Liang J, Yeleswaram S, et al. Preliminary clinical activity of a topical JAK1/2 inhibitor in the treatment of psoriasis. $J$ Am Acad Dermatol. (2012) 67:658-64. doi: 10.1016/j.jaad.2011.12.018

63. Punwani N, Burn T, Scherle P, Flores R, Shi J, Collier P, et al. Downmodulation of key inflammatory cell markers with a topical Janus kinase $1 / 2$ inhibitor. $B r \quad J$ Dermatol. (2015) 173:989-97. doi: 10.1111/bjd.13994

64. Kim B, Nasir A, Papp K, Parish LC, Kuligowski M, Venturanza M, et al. A phase 2, randomized, dose-ranging, vehicle- and active-controlled study to evaluate the safety and efficacy of topical ruxolitinib in adult patients with atopic dermatitis. In: Presented at: The 27th European Academy of Dermatology and Venereology (EADV) Congress. Paris (2018).

65. Raoof T, Kircik L, Kuligowski M, Venturanza M, Sun K, Tan J. 12-Week efficacy and safety data of ruxolitinib cream in adult patients with atopic dermatitis: results from a phase 2 study. In: Presented at: The 24th World Congress of Dermatology (WCD). Milan (2019).

66. Rosmarin D, Pandya A, Lebwohl M, Grimes P, Hamzavi I, Gottlieb AB, et al. Efficacy and safety of ruxolitinib cream for the treatment of Vitiligo: results of a 24-week randomized, double-blind, dose-ranging, vehicle-controlled study. In: Presented at the 24th World Congress of Dermatology. Milan (2019).

67. Rothstein B, Joshipura D, Saraiya A, Abdat R, Ashkar H, Turkowski Y, et al. Treatment of vitiligo with the topical Janus kinase inhibitor ruxolitinib. J Am Acad Dermatol. (2017). 76:1054-60 e1051. doi: 10.1016/j.jaad.2017.02.049

68. Strazzulla LC, Wang EHC, Avila L, Lo Sicco K, Brinster N, Christiano $\mathrm{AM}$, et al. Alopecia areata: Disease characteristics, clinical evaluation, and new perspectives on pathogenesis. J Am Acad Dermatol. (2018) 78:1-12. doi: 10.1016/j.jaad.2017.04.1141

69. Paus R, Nickoloff BJ, Ito T. A 'hairy' privilege. Trends Immunol. (2005) 26:32-40. doi: 10.1016/j.it.2004.09.014

70. Gilhar A, Etzioni A, Paus R. Alopecia areata. N Engl J Med. (2012) 366:151525. doi: 10.1056/NEJMra1103442

71. Mcelwee KJ, Gilhar A, Tobin DJ, Ramot Y, Sundberg JP, Nakamura M, et al. What causes alopecia areata? Exp Dermatol. (2013) 22:609-26. doi: 10.1111/exd.12209

72. Guo H, Cheng Y, Shapiro J, Mcelwee K. The role of lymphocytes in the development and treatment of alopecia areata. Expert Rev Clin Immunol. (2015) 11:1335-51. doi: 10.1586/1744666X.2015.1085306

73. Paus R, Christoph T, Muller-Rover S. Immunology of the hair follicle: a short journey into terra incognita. J Investig Dermatol Symp Proc. (1999) 4:226-34. doi: 10.1038/sj.jidsp.5640217

74. Kang H, Wu WY, Lo BK, Yu M, Leung G, Shapiro J, et al. Hair follicles from alopecia areata patients exhibit alterations in immune privilege-associated gene expression in advance of hair loss. J Invest Dermatol. (2010) 130:267780. doi: 10.1038/jid.2010.180

75. Breitkopf T, Lo BK, Leung G, Wang E, Yu M, Carr N, et al. Somatostatin expression in human hair follicles and its potential role in immune privilege. J Invest Dermatol. (2013) 133:1722-30. doi: 10.1038/jid.2013.53

76. Wang X, Marr AK, Breitkopf T, Leung G, Hao J, Wang E, et al. Hair follicle mesenchyme-associated $\mathrm{PD}-\mathrm{L} 1$ regulates $\mathrm{T}$-cell activation induced apoptosis: a potential mechanism of immune privilege. J Invest Dermatol. (2014) 134:736-45. doi: 10.1038/jid.2013.368

77. Mcelwee KJ, Boggess D, King LEJr, Sundberg JP. Experimental induction of alopecia areata-like hair loss in $\mathrm{C} 3 \mathrm{H} / \mathrm{HeJ}$ mice using full-thickness skin grafts. J Invest Dermatol. (1998) 111:797-803. doi: 10.1046/j.1523-1747.1998.00380.x

78. Mcelwee KJ, Boggess D, Olivry T, Oliver RF, Whiting D, Tobin DJ, et al. Comparison of alopecia areata in human and nonhuman mammalian species. Pathobiology. (1998) 66:90-107. doi: 10.1159/000028002

79. Shin JM, Choi DK, Sohn KC, Koh JW, Lee YH, Seo YJ, et al. Induction of alopecia areata in $\mathrm{C} 3 \mathrm{H} / \mathrm{HeJ}$ mice using polyinosinicpolycytidylic acid (poly[I:C]) and interferon-gamma. Sci Rep. (2018) 8:12518. doi: 10.1038/s41598-018-30997-3

80. Jabbari A, Dai Z, Xing L, Cerise JE, Ramot Y, Berkun Y, et al. Reversal of alopecia areata following treatment with the JAK1/2 inhibitor baricitinib. EBioMedicine. (2015) 2:351-5. doi: 10.1016/j.ebiom.2015.02.015

81. Xing L, Dai Z, Jabbari A, Cerise JE, Higgins CA, Gong W, et al. Alopecia areata is driven by cytotoxic T lymphocytes and is reversed by JAK inhibition. Nat Med. (2014) 20:1043-9. doi: 10.1038/nm.3645

82. Ghoreishi M, Martinka M, Dutz JP. Type 1 interferon signature in the scalp lesions of alopecia areata. Br J Dermatol. (2010) 163:57-62. doi: 10.1111/j.1365-2133.2010.09775.x

83. De Jong A, Jabbari A, Dai Z, Xing L, Lee D, Li MM, et al. Highthroughput $\mathrm{T}$ cell receptor sequencing identifies clonally expanded CD8+ $\mathrm{T}$ cell populations in alopecia areata. JCI Insight. (2018) 3:121949. doi: 10.1172/jci.insight.121949

84. Fuentes-Duculan J, Gulati N, Bonifacio KM, Kunjravia N, Zheng X, Suarez-Farinas $\mathrm{M}$, et al. Biomarkers of alopecia areata disease activity 
and response to corticosteroid treatment. Exp Dermatol. (2016) 25:282-6. doi: 10.1111/exd.12918

85. Freyschmidt-Paul P, Mcelwee KJ, Hoffmann R, Sundberg JP, Vitacolonna $\mathrm{M}$, Kissling $\mathrm{S}$, et al. Interferon-gamma-deficient mice are resistant to the development of alopecia areata. Br J Dermatol. (2006) 155:515-21. doi: 10.1111/j.1365-2133.2006.07377.x

86. Ito T, Ito N, Bettermann A, Tokura Y, Takigawa M, Paus R. Collapse and restoration of MHC class-I-dependent immune privilege: exploiting the human hair follicle as a model. Am J Pathol. (2004) 164:623-34. doi: 10.1016/S0002-9440(10)63151-3

87. Petukhova L, Duvic M, Hordinsky M, Norris D, Price V, Shimomura Y, et al. Genome-wide association study in alopecia areata implicates both innate and adaptive immunity. Nature. (2010) 466:113-7. doi: 10.1038/nature09114

88. Pratt CH, King LE Jr, Messenger AG, Christiano AM, Sundberg JP. Alopecia areata. Nat Rev Dis Primers. (2017) 3:17011. doi: 10.1038/nrdp.2017.11

89. Abou Rahal J, Kurban M, Kibbi AG, Abbas O. Plasmacytoid dendritic cells in alopecia areata: missing link? J Eur Acad Dermatol Venereol. (2016) 30:119-23. doi: $10.1111 /$ jdv.12932

90. Charles J, Chaperot L, Salameire D, Di Domizio J, Aspord C, Gressin R, et al. Plasmacytoid dendritic cells and dermatological disorders: focus on their role in autoimmunity and cancer. Eur J Dermatol. (2010) 20:16-23. doi: 10.1684/ejd.2010.0816

91. Mcphee CG, Duncan FJ, Silva KA, King LEJr, Hogenesch H, Roopenian DC, et al. Increased expression of Cxcr3 and its ligands, $\mathrm{Cxcl} 9$ and Cxcl10, during the development of alopecia areata in the mouse. J Invest Dermatol. (2012) 132:1736-8. doi: 10.1038/jid.2012.17

92. Kuo PT, Zeng Z, Salim N, Mattarollo S, Wells JW, Leggatt GR. The role of CXCR3 and its chemokine ligands in skin disease and cancer. Front Med. (2018) 5:271. doi: 10.3389/fmed.2018.00271

93. Jabri B, Abadie V. IL-15 functions as a danger signal to regulate tissueresident T cells and tissue destruction. Nat Rev Immunol. (2015) 15:771-83. doi: $10.1038 /$ nri3919

94. Cooley ID, Read KA, Oestreich KJ. Trans-presentation of IL-15 modulates STAT5 activation and Bcl-6 expression in TH1 cells. Sci Rep. (2015) 5:15722. doi: $10.1038 /$ srep 15722

95. Betz RC, Petukhova L, Ripke S, Huang H, Menelaou A, Redler S, et al. Genome-wide meta-analysis in alopecia areata resolves HLA associations and reveals two new susceptibility loci. Nat Commun. (2015) 6:5966. doi: $10.1038 /$ ncomms6966

96. O'shea JJ, Plenge R. JAK and STAT signaling molecules in immunoregulation and immune-mediated disease. Immunity. (2012) 36:542-50. doi: 10.1016/j.immuni.2012.03.014

97. Harel S, Higgins CA, Cerise JE, Dai Z, Chen JC, Clynes R, et al. Pharmacologic inhibition of JAK-STAT signaling promotes hair growth. Sci Adv. (2015) 1:e1500973. doi: 10.1126/sciadv.1500973

98. Meephansan J, Thummakriengkrai J, Ponnikorn S, Yingmema W, Deenonpoe R, Suchonwanit P. Efficacy of topical tofacitinib in promoting hair growth in non-scarring alopecia: possible mechanism via VEGF induction. Arch Dermatol Res. (2017) 309:729-38. doi: $10.1007 / \mathrm{s} 00403-017-1777-5$

99. Craiglow BG, King BA. Killing two birds with one stone: oral tofacitinib reverses alopecia universalis in a patient with plaque psoriasis. J Invest Dermatol. (2014) 134:2988-90. doi: 10.1038/jid.2014.260

100. Higgins E, Al Shehri T, Mcaleer MA, Conlon N, Feighery C, Lilic D, et al. Use of ruxolitinib to successfully treat chronic mucocutaneous candidiasis caused by gain-of-function signal transducer and activator of transcription 1 (STAT1) mutation. J Allergy Clin Immunol. (2015) 135:551-3. doi: 10.1016/j.jaci.2014.12.1867

101. Pieri L, Guglielmelli P, Vannucchi AM. Ruxolitinib-induced reversal of alopecia universalis in a patient with essential thrombocythemia. Am J Hematol. (2015) 90:82-3. doi: 10.1002/ajh.23871

102. Harris JE, Rashighi M, Nguyen N, Jabbari A, Ulerio G, Clynes R, et al. Rapid skin repigmentation on oral ruxolitinib in a patient with coexistent vitiligo and alopecia areata (AA). J Am Acad Dermatol. (2016) 74:370-1. doi: 10.1016/j.jaad.2015.09.073

103. Boyadzhiev M, Marinov L, Boyadzhiev V, Iotova V, Aksentijevich I, Hambleton S. Disease course and treatment effects of a JAK inhibitor in a patient with CANDLE syndrome. Pediatr Rheumatol Online J. (2019) 17:19. doi: 10.1186/s12969-019-0322-9

104. Jabbari A, Sansaricq F, Cerise J, Chen JC, Bitterman A, Ulerio G, et al. An Open-Label Pilot Study to Evaluate the Efficacy of Tofacitinib in Moderate to Severe Patch-Type Alopecia Areata, Totalis, and Universalis. J Invest Dermatol. (2018) 138:1539-45. doi: 10.1016/j.jid.2018.01.032

105. Craiglow BG, Liu LY, King BA. Tofacitinib for the treatment of alopecia areata and variants in adolescents. J Am Acad Dermatol. (2017) 76:29-32. doi: 10.1016/j.jaad.2016.09.006

106. Liu LY, Craiglow BG, Dai F, King BA. Tofacitinib for the treatment of severe alopecia areata and variants: a study of 90 patients. J Am Acad Dermatol. (2017) 76:22-8. doi: 10.1016/j.jaad.2016.09.007

107. Liu LY, Strassner JP, Refat MA, Harris JE, King BA. Repigmentation in vitiligo using the Janus kinase inhibitor tofacitinib may require concomitant light exposure. J Am Acad Dermatol. (2017) 77:675-82 e671. doi: 10.1016/j.jaad.2017.05.043

108. Craiglow BG, King BA. Tofacitinib citrate for the treatment of vitiligo: a pathogenesis-directed therapy. JAMA Dermatol. (2015) 151:1110-2. doi: 10.1001/jamadermatol.2015.1520

109. Bayart CB, Deniro KL, Brichta L, Craiglow BG, Sidbury R. Topical Janus kinase inhibitors for the treatment of pediatric alopecia areata. J Am Acad Dermatol. (2017) 77:167-70. doi: 10.1016/j.jaad.2017.03.024

110. Nestle FO, Kaplan DH, Barker J. Psoriasis. N Engl J Med. (2009) 361:496-509. doi: 10.1056/NEJMra0804595

111. Afzali B, Lombardi G, Lechler RI, Lord GM. The role of T helper 17 (Th17) and regulatory $\mathrm{T}$ cells (Treg) in human organ transplantation and autoimmune disease. Clin Exp Immunol. (2007) 148:32-46. doi: 10.1111/j.1365-2249.2007.03356.x

112. Albanesi C, De Pita O, Girolomoni G. Resident skin cells in psoriasis: a special look at the pathogenetic functions of keratinocytes. Clin Dermatol. (2007) 25:581-8. doi: 10.1016/j.clindermatol.2007.08.013

113. Lee E, Trepicchio WL, Oestreicher JL, Pittman D, Wang F, Chamian F, et al. Increased expression of interleukin 23 p19 and p40 in lesional skin of patients with psoriasis vulgaris. J Exp Med. (2004) 199:125-30. doi: 10.1084/jem.20030451

114. Sutton CE, Lalor SJ, Sweeney CM, Brereton CF, Lavelle EC, Mills KH. Interleukin-1 and IL-23 induce innate IL-17 production from gammadelta $\mathrm{T}$ cells, amplifying Th17 responses and autoimmunity. Immunity. (2009) 31:331-41. doi: 10.1016/j.immuni.2009.08.001

115. Zheng Y, Danilenko DM, Valdez P, Kasman I, Eastham-Anderson $\mathrm{J}$, Wu $\mathrm{J}$, et al. Interleukin-22, a $\mathrm{T}(\mathrm{H}) 17$ cytokine, mediates IL-23induced dermal inflammation and acanthosis. Nature. (2007) 445:648-51. doi: 10.1038/nature05505

116. Boutet MA, Nerviani A, Gallo Afflitto G, Pitzalis C. Role of the IL23/IL-17 axis in psoriasis and psoriatic arthritis: the clinical importance of its divergence in skin and joints. Int J Mol Sci. (2018) 19:E530. doi: 10.3390/ijms 19020530

117. Belge K, Bruck J, Ghoreschi K. Advances in treating psoriasis. F1000Prime Rep. (2014) 6:4. doi: 10.12703/P6-4

118. Nada HR, El Sharkawy DA, Elmasry MF, Rashed LA, Mamdouh S. Expression of Janus Kinase 1 in vitiligo and psoriasis before and after narrow band UVB: a case-control study. Arch Dermatol Res. (2018) 310:39-46. doi: 10.1007/s00403-017-1792-6

119. Wei L, Laurence A, Elias KM, O'shea JJ. IL-21 is produced by Th17 cells and drives IL-17 production in a STAT3-dependent manner. J Biol Chem. (2007) 282:34605-10. doi: 10.1074/jbc.M705100200

120. Camporeale A, Poli V. IL-6, IL-17 and STAT3: a holy trinity in autoimmunity? Front Biosci. (2012) 17:2306-26. doi: 10.2741/4054

121. Van Der Fits L, Mourits S, Voerman JS, Kant M, Boon L, Laman JD, et al. Imiquimod-induced psoriasis-like skin inflammation in mice is mediated via the IL-23/IL-17 axis. J Immunol. (2009) 182:5836-45. doi: 10.4049/jimmunol.0802999

122. Tanimoto A, Shinozaki Y, Yamamoto Y, Katsuda Y, Taniai-Riya E, Toyoda $\mathrm{K}$, et al. A novel JAK inhibitor JTE-052 reduces skin inflammation and ameliorates chronic dermatitis in rodent models: comparison with conventional therapeutic agents. Exp Dermatol. (2018) 27:22-9. doi: $10.1111 /$ exd.13370 
123. Ghoreschi K, Jesson MI, Li X, Lee JL, Ghosh S, Alsup JW, et al. Modulation of innate and adaptive immune responses by tofacitinib (CP-690,550). J Immunol. (2011) 186:4234-43. doi: 10.4049/jimmunol.1003668

124. Morelli M, Scarponi C, Mercurio L, Facchiano F, Pallotta S, Madonna S, et al. Selective immunomodulation of inflammatory pathways in keratinocytes by the Janus Kinase (JAK) inhibitor tofacitinib: implications for the employment of JAK-targeting drugs in psoriasis. J Immunol Res. (2018) 2018:7897263. doi: 10.1155/2018/7897263

125. Chang BY, Zhao F, He X, Ren H, Braselmann S, Taylor V, et al. JAK3 inhibition significantly attenuates psoriasiform skin inflammation in CD18 mutant PL/J mice. J Immunol. (2009) 183:2183-92. doi: 10.4049/jimmunol.0804063

126. Karaghiosoff M, Neubauer H, Lassnig C, Kovarik P, Schindler H, Pircher $\mathrm{H}$, et al. Partial impairment of cytokine responses in Tyk2-deficient mice. Immunity. (2000) 13:549-60. doi: 10.1016/S1074-7613(00)00054-6

127. Shimoda K, Kato K, Aoki K, Matsuda T, Miyamoto A, Shibamori M, et al. Tyk2 plays a restricted role in IFN alpha signaling, although it is required for IL-12-mediated T cell function. Immunity. (2000) 13:561-71. doi: 10.1016/S1074-7613(00)00055-8

128. Ishizaki M, Muromoto R, Akimoto T, Sekine Y, Kon S, Diwan M, et al. Tyk2 is a therapeutic target for psoriasis-like skin inflammation. Int Immunol. (2014) 26:257-67. doi: 10.1093/intimm/dxt062

129. Works MG, Yin F, Yin CC, Yiu Y, Shew K, Tran TT, et al. Inhibition of TYK2 and JAK1 ameliorates imiquimod-induced psoriasis-like dermatitis by inhibiting IL-22 and the IL-23/IL-17 axis. J Immunol. (2014) 193:3278-87. doi: 10.4049/jimmunol.1400205

130. Sano S, Chan KS, Carbajal S, Clifford J, Peavey M, Kiguchi K, et al. Stat3 links activated keratinocytes and immunocytes required for development of psoriasis in a novel transgenic mouse model. Nat Med. (2005) 11:43-9. doi: $10.1038 / \mathrm{nm} 1162$

131. Miyoshi K, Takaishi M, Nakajima K, Ikeda M, Kanda T, Tarutani M, et al. Stat 3 as a therapeutic target for the treatment of psoriasis: a clinical feasibility study with STA-21, a Stat3 inhibitor. J Invest Dermatol. (2011) 131:108-17. doi: 10.1038/jid.2010.255

132. Nakajima K, Kanda T, Takaishi M, Shiga T, Miyoshi K, Nakajima $\mathrm{H}$, et al. Distinct roles of IL-23 and IL-17 in the development of psoriasis-like lesions in a mouse model. J Immunol. (2011) 186:4481-9. doi: 10.4049/jimmunol.1000148

133. Ludbrook VJ, Hicks KJ, Hanrott KE, Patel JS, Binks MH, Wyres MR, et al. Investigation of selective JAK1 inhibitor GSK2586184 for the treatment of psoriasis in a randomized placebo-controlled phase IIa study. $\mathrm{Br}$ J Dermatol. (2016) 174:985-95. doi: 10.1111/bjd.14399

134. Ports WC, Feldman SR, Gupta P, Tan H, Johnson TR, Bissonnette R. Randomized pilot clinical trial of tofacitinib solution for plaque psoriasis: challenges of the intra-subject study design. J Drugs Dermatol. (2015) 14:777-84.

135. Kruger C, Schallreuter KU. A review of the worldwide prevalence of vitiligo in children/adolescents and adults. Int J Dermatol. (2012) 51:1206-12. doi: 10.1111/j.1365-4632.2011.05377.x

136. Boniface K, Seneschal J, Picardo M, Taieb A. Vitiligo: focus on clinical aspects, immunopathogenesis, and therapy. Clin Rev Allergy Immunol. (2018) 54:52-67. doi: 10.1007/s12016-017-8622-7

137. Radtke MA, Schafer I, Gajur A, Langenbruch A, Augustin M. Willingnessto-pay and quality of life in patients with vitiligo. Br J Dermatol. (2009) 161:134-9. doi: 10.1111/j.1365-2133.2009.09091.x

138. Talsania N, Lamb B, Bewley A. Vitiligo is more than skin deep: a survey of members of the Vitiligo Society. Clin Exp Dermatol. (2010) 35:736-9. doi: 10.1111/j.1365-2230.2009.03765.x
139. Ogg GS, Rod Dunbar P, Romero P, Chen JL, Cerundolo V. High frequency of skin-homing melanocyte-specific cytotoxic T lymphocytes in autoimmune vitiligo. J Exp Med. (1998) 188:1203-8. doi: 10.1084/jem.188. 6.1203

140. Van Den Boorn JG, Konijnenberg D, Dellemijn TA, Van Der Veen JP, Bos JD, Melief CJ, et al. Autoimmune destruction of skin melanocytes by perilesional T cells from vitiligo patients. J Invest Dermatol. (2009) 129:222032. doi: 10.1038/jid.2009.32

141. Rashighi M, Agarwal P, Richmond JM, Harris TH, Dresser K, Su MW, et al. CXCL10 is critical for the progression and maintenance of depigmentation in a mouse model of vitiligo. Sci Transl Med. (2014) 6:223ra223. doi: 10.1126/scitranslmed.3007811

142. Regazzetti C, Joly F, Marty C, Rivier M, Mehul B, Reiniche P, et al. Transcriptional analysis of vitiligo skin reveals the alteration of WNT pathway: a promising target for repigmenting vitiligo patients. J Invest Dermatol. (2015) 135:3105-14. doi: 10.1038/jid. 2015.335

143. Abdallah M, El-Mofty M, Anbar T, Rasheed H, Esmat S, Al-Tawdy A, et al CXCL-10 and Interleukin- 6 are reliable serum markers for vitiligo activity: a multicenter cross-sectional study. Pigment Cell Melanoma Res. (2018) 31:330-6. doi: 10.1111/pcmr.12667

144. Strassner JP, Rashighi M, Ahmed Refat M, Richmond JM, Harris JE. Suction blistering the lesional skin of vitiligo patients reveals useful biomarkers of disease activity. J Am Acad Dermatol. (2017) 76:847-55 e845. doi: 10.1016/j.jaad.2016.12.021

145. Richmond JM, Masterjohn E, Chu R, Tedstone J, Youd ME, Harris JE. CXCR3 depleting antibodies prevent and reverse vitiligo in mice. J Invest Dermatol. (2017) 137:982-5. doi: 10.1016/j.jid.2016. 10.048

146. Richmond JM, Bangari DS, Essien KI, Currimbhoy SD, Groom JR, Pandya AG, et al. Keratinocyte-derived chemokines orchestrate T-cell positioning in the epidermis during vitiligo and may serve as biomarkers of disease. J Invest Dermatol. (2017) 137:350-8. doi: 10.1016/j.jid.2016. 09.016

147. Abdou AG, Maraee A, Yassien H, Sarhan M. Immunohistochemistry of Janus Kinase 1 (JAK1) Expression in Vitiligo. J Pathol Transl Med. (2018) 52:363-8. doi: 10.4132/jptm.2018.09.18

148. Relke N, Gooderham M. The use of janus kinase inhibitors in Vitiligo: a review of the literature. J Cutan Med Surg. (2019) 23:298-306. doi: 10.1177/1203475419833609

149. Kim SR, Heaton H, Liu LY, King BA. Rapid repigmentation of vitiligo using tofacitinib plus low-dose, narrowband UV-B phototherapy. JAMA Dermatol. (2018) 154:370-1. doi: 10.1001/jamadermatol.2017. 5778

150. Choy EH. Clinical significance of Janus Kinase inhibitor selectivity. Rheumatology. (2019) 58:953-62. doi: 10.1093/rheumatology/key339

151. Fragoulis GE, Mcinnes IB, Siebert S. JAK-inhibitors. New players in the field of immune-mediated diseases, beyond rheumatoid arthritis. Rheumatology. (2019) 58:i43-54. doi: 10.1093/rheumatology/key276

Conflict of Interest: MH, FK, and PS are employees of Incyte Corporation.

Copyright (c) 2019 Howell, Kuo and Smith. This is an open-access article distributed under the terms of the Creative Commons Attribution License (CC BY). The use, distribution or reproduction in other forums is permitted, provided the original author(s) and the copyright owner(s) are credited and that the original publication in this journal is cited, in accordance with accepted academic practice. No use, distribution or reproduction is permitted which does not comply with these terms. 